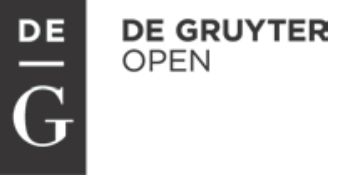

\title{
EXPLAINING TURNOUT DECLINE IN POST-COMMUNIST COUNTRIES: THE IMPACT OF MIGRATION
}

\author{
MIRCEA COMȘA ${ }^{1}$
}

\begin{abstract}
Turnout decline in former communist countries has attracted a great deal of scholarly attention. In this paper, I re-test some of the previous hypotheses on new data and I propose a new hypothesis that considers the impact of external migration. Using multivariate regression models on a dataset of 272 presidential and parliamentary elections held in 30 post-communist countries between 1989 and 2012, I have found strong support for the "migration hypothesis": other things being equal, an increase of migration rate by 1 percentage point reduces voter turnout by around 0.4 percentage points. Most of the previous hypotheses related to causes of turnout decline are supported too.
\end{abstract}

Keywords: voter turnout, turnout decline, migration, post-communist countries

\section{Introduction ${ }^{2}$}

Turnout decline represents a major theme in the field of electoral studies. Scholars and politicians agree that political participation is one of the main pillars of democracy. Without citizens' involvement (seen as a continuum from choosing representatives to participating in the decision-making process) a democracy cannot function properly (Dahl, 1998; Verba et al., 1995). Participation in the election of representatives is the "most frequent and basic form of political participation" (Blais, 2000; Verba et al., 1995). From a normative perspective that gives preference to high levels of participation (Lijphart, 1997) a low turnout is indicative of a weak democracy. Moreover, low turnout can be seen as a threat to democracy because it implies a lack of legitimacy of the elected

\footnotetext{
${ }^{1}$ Sociology Department, Babeș-Bolyai University Cluj-Napoca, e-mail: mcomsa@socasis.ubbcluj.ro.

2 This paper was supported by the CNCS-UEFISCDI under grants PN-II-ID-PCE-2011-3-0669 and PN-II-ID-PCE-2011-3-0210. The author wishes to thank to Romana Careja, Bogdan Voicu, and Camil Postelnicu for their helpful comments and suggestions on previous versions of this paper.
} 
government, which leads to a lower acceptance of governmental decisions (Czesnik, 2006; Hadjar and Beck, 2010). Even more, low turnout is associated with unequal political representation of different socio-demographic groups (Patterson, 2002; Teixeira, 1992; Wattenberg, 2002; White and McAllister 2007) and consequently their unequal political influence (Lijphart 1997, 1998). In addition, low and falling turnout is considered a sign of disengagement and lower(ing) commitment to democratic norms and duties (Norris, 1999; Teixeira, 1992). In the context of new democracies, these concerns are even more relevant as they bring into the spotlight the unidirectionality of the democratization process (Huntington, 1991; Lijphart, 2000).

Turnout decline in former communist countries has attracted a great deal of scholarly attention. In order to explain turnout level and/or decline, most of the previous studies (Brady and McNulty, 2011; Inglehartand Catterberg, 2002; Kostadinova, 2003; Pacek, et al., 2009; Steiner, 2010) have proposed and tested hypotheses which focused on factors such as post-communist demobilization, socialization period, civil society, social capital, "post-honeymoon effect", deteriorating economic and political conditions, "electoral stakes", economic globalization and supra-national integration. In this paper, I re-test some of these hypotheses on new data and I propose a novel hypothesis that considers the fact that the former communist countries have experienced high rates of their citizens' transnational migration (I include here temporary, short and long term transnational migration). Using multivariate regression models on the original dataset of 272 presidential and parliamentary elections held in 30 post-communist countries between 1989 and 2012, I have found strong support for the "migration hypothesis": other things being equal, on average, an increase of migration rate by 1 percentage point reduces voter turnout by around 0.4 percentage points. Most of the previous hypotheses related to causes of turnout decline are supported too.

The paper is structured as follows. Section 2 presents empirical evidence of turnout decline in post-communist states after 1990. Section 3 discusses the main explanatory theories of turnout decline, then the theoretical link between migration and voter turnout is presented and discussed (Section 4). Section 5 outlines the situation of post-communist transnational migration since 1990. Unlike Western European countries, states from Central and Eastern Europe have negative balances of transnational migration, i.e. they "send" more migrants than they receive. Sections 6 and 7 present the data, the method, the analyses and the main findings. Finally, the implications of these findings for different areas (democratic theory, citizen's political rights, election results, and puzzles about turnout explanations) are discussed. 


\section{Turnout decline in post-communist states}

Most studies show that voter turnout (VT) is in a process of ongoing decline in post-communist states (Bernhagen and Marsh, 2007; Kostadinova and Power, 2007; Kostelka, 2014). This decline was theoretically expected because turnout in the founding elections reflect general hope and enthusiasm, but afterwards it declines due to the fact that "voters learn that elections are not a panacea and become less excited about the transition to democracy" (Turner, 1993). Nevertheless, an IDEA study (Lâopez Pintor, Gratschew, Adåimåi, \& International Institute for Democracy and Electoral Assistance, 2002) did not find significant difference in VT between the first election and other subsequent elections (second or third wave) in new democracies. On the other hand, taking into account a larger time span and including relevant covariates, later studies identify a downward trend in VT after the founding elections (Bernhagen and Marsh, 2007; Kostadinova, 2003; Kostadinova and Power, 2007). Moreover, the descending trend continues for the subsequent elections (from the third to the fifth wave), even for the already lower rates. Controlling for institutional and socio-economic factors, the drop was 8 percentage points for the second election, 6 for the third and 5 for the fourth election (Kostadinova, 2003).

Recent data about voter turnout (VT) in former communist countries indicate similar trends across the region (Figure 1). Since the fall of communist regimes, VT has declined in average by almost one percent per year. If the average turnout was around $80 \%$ in the case of founding elections, the more recent ones have a turnout as low as $60-64 \%$. This descending trend is common for most of the former communist countries. Only six out of the 30 countries analyzed here present a different picture: turnout is relatively stable in Hungary and is slightly increasing in Armenia, Belarus, Kazakhstan, Serbia, and Tajikistan.

Figure 1. Turnout decline in former communist countries (1989-2012)
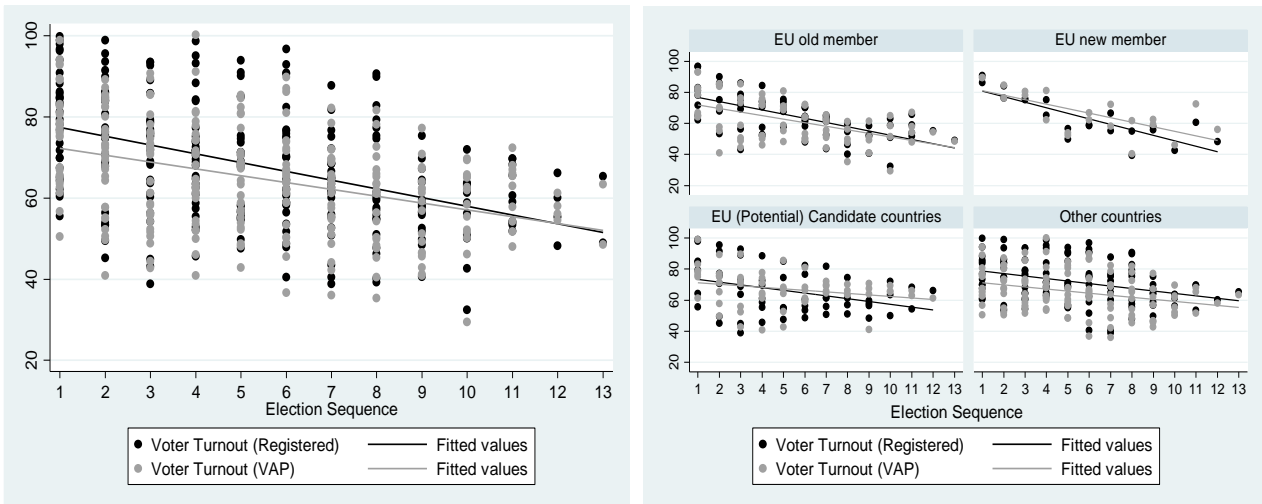


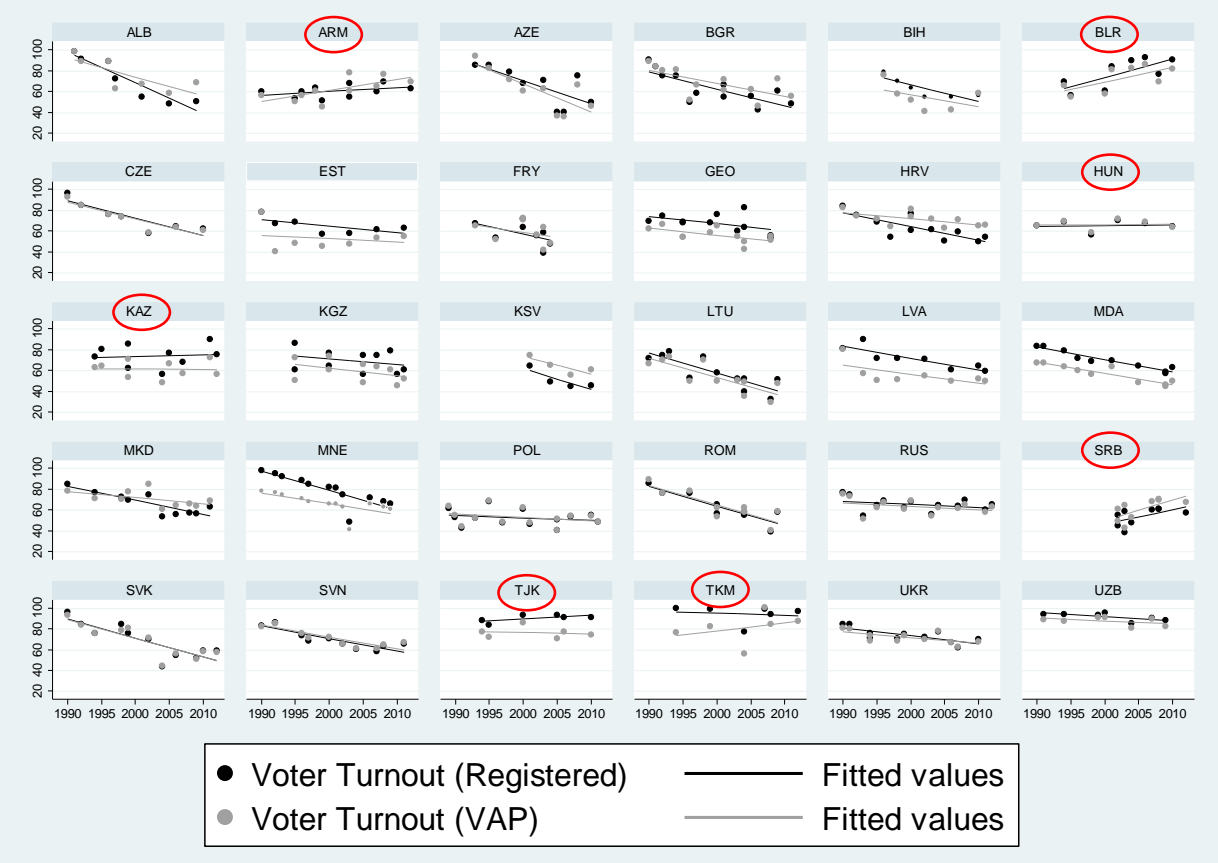

Source: Author's calculations based on IDEA Voter Turnout Database (VAP = voting age population).

\section{Explaining turnout decline}

Why is turnout declining after the fall of communist regimes? Based on the explanatory frameworks identified in the Western World, and considering the particularities of the East and Central Asia, previous studies have proposed several hypotheses.

According to Rose (1995) turnout decline is the result of post-communist demobilization: because the citizens are now free, they chose to not participate. ${ }^{3}$ Rose's hypothesis is not fully supported. Considering electorates from Poland, Hungary and Czech Republic, Kostelka (2010) has found, on average, a higher VT among cohorts who socialized under the communist regime compared to those who socialized during the democratic period. Other factors that could lower the turnout are a weak civil society and a low level of social capital (Howard, 2003;

\footnotetext{
${ }^{3}$ From the opposite view, one can argue that only in democracies electoral choices are real and meaningful and, consequently, people should participate more (Bernhagen \& Marsh 2007).
} 
Norris, 2002), but their effect is also not clear (Norris, 2002). Moreover, because these two explanatory variables are rather invariant (at least in the first decade of post-communist period), these hypotheses are rather static (Kostelka, 2010), and therefore are less adequate for explaining a long term phenomenon.

A second set of hypotheses adopt a more dynamic approach. The "posthoneymoon effect" hypothesis (Inglehart and Catterberg, 2002; Kostadinova, 2003) states that right after the fall of communism citizens are enthusiast, have high expectations but, shortly later, they become deceived and, consequently, absenteeism is growing. Even if this hypothesis has found support, it refers to the period shortly after the fall of communist regimes and, consequently, it cannot explain the persistence of turnout decline in the later elections. A more adequate explanation from a long-term perspective asserts that turnout decline is linked to the deteriorating economic and political conditions. The first years of new democracies have been characterized by severe and growing economic hardship (such as hyperinflation and high unemployment rates) which had a negative impact on VT (Bell, 2001; Fauvelle-Aymar and Stegmaier, 2008; Mason, 2003; Pacek, 1994; Pacek, Pop-Eleches, and Tucker, 2009; Tworzecki 2003). Other studies (Blais, 2000; Blais and Aarts, 2006; Blais and Dobrzynska, 1998; Fornos, Power, and Garand, 2004; Kostadinova, 2003) report no clear relation between the economic conjuncture and turnout (Blais, 2006). ${ }^{4}$ After an initial phase of relative stability, the political conditions in post-communist states have worsened, including extreme inter- and intra-party instability, political scandals, corruption, illegal practices within parties (Hutcheson, 2004; Kostadinova, 2003; Kostadinova, 2009; Stockemer, LaMontagne, and Scruggs, 2013; Sundström and Stockemer, 2013; White and McAllister, 2004). Such processes could contribute to turnout decline. Political instability, measured as party fractionalization, is generally negatively correlated with turnout (Blais, 2006; Blais and Dobrzynska, 1998; Kostadinova, 2003), even if a meta-analysis (Geys, 2006) has not found a conclusive relation.

The third hypothesis, the "electoral stakes" hypothesis (Pacek et al., 2009), states that after the fall of communism people gradually learnt to identify which elections are more important and, consequently, worth their time and effort. This hypothesis has found empirical support even after controlling for a series of alternative explanations (Pacek et al., 2009).

A fourth set of factors leading to turnout decline are linked to economic globalization (Brady and McNulty, 2011; Steiner, 2010). According to this approach, international economic integration reduces the ability of national

\footnotetext{
${ }^{4}$ Economic downturns increase turnout at high and low levels of welfare spending, but depress it at intermediate levels, so, overall effect is nil (Radcliff 1992).
} 
governments to shape outcomes; citizens are aware of such constraints; because the type and size of benefits are depending less on the national governments, citizens vote at lower rates. This hypothesis was tested only in the case of OECD countries (Brady and McNulty, 2011; Steiner, 2010), but I expect it to be true for the former communist countries as well. Following the same line of thought, integration in supra-national political structures could have similar effect, so one should consider it.

\section{Migration and turnout decline: a theoretical link}

All previous studies have ignored (temporary) transnational migration as a potential explanatory variable of turnout decline. In the case of former communist states, transnational migration is a relatively new and growing issue. Migration can have a major impact on VT due to several factors such as the cost of voting (time and money), being part of a social network, and bureaucratic barriers.

One of most common theories, the cost-benefit analysis, states that a person will vote when the inequality $C<P * B$ is satisfied, where $C$ represent the cost of voting, B the benefits associated with "winning" elections and $\mathrm{P}$ the probability that a single vote will decide the winner (Downs, 1957). Because the returns (B or PB term) from voting are usually low, a small increase in the cost of voting may significantly reduce turnout (Downs, 1957: 266; Niemi, 1976). Sometimes the term D - civic duty - is added to the right side of the equation.

According to Downs (1957) the principal cost of voting is time: one needs time to gather information about the political candidates, to register, to deliberate, to find and to go to the polling station, and to vote. In addition to time, if the polling station is far from home, some amount of money must be spent on travelling. Because time and money are scarce resources, voting is inherently costly. Generally, information and decision-making costs are fairly low (Aldrich, 1993). The direct costs associated with the act of voting itself are also low (Niemi, 1976). Consequently, distance to the polling stations, measured by time and travel cost, has most probably a significant impact on turnout decision. More clearly, it is expected that a higher distance will reduce the probability to cast a vote in person. This applies to in-person vote. If the electoral legislation allows mail or Internet voting, the distance to the pools becomes irrelevant. That is why multivariate analyses should include as control variables these alternative channels of casting a vote.

The studies about the influence of distance to the polling station on turnout clearly identify a negative, nonlinear relation (Bhatti, 2012; Brady and McNulty, 2011; Dyck and Gimpel, 2005; Haspel and Knotts, 2005; McNulty, 
Dowling, and Ariotti, 2009). For the context of our research, it is important to add that all these studies are about local elections and that the maximum distance to the polling stations is generally low. ${ }^{5}$ Moreover, a small increase in the distance to the polling station reduces the turnout quite much, ${ }^{6}$ but the relation is non-linear (it declines as the distance becomes longer) being mediated by the presence of a car in the household.

If so small distances have such a large impact on turnout declining, one can expect that migrants vote at much lower rates than their conationals in national election. This would happen because the number of polling stations from abroad is small 7 and, consequently, the average distance to the closest polling station is much higher. Even if a migrant is willing to vote, the cost of voting is generally so high in terms of time and money that the turnout probability is close to zero in the case of migrants. Besides the distance factor, the costs of finding relevant information about parties or candidates (Lafleur and Chelius, 2011) and searching for the polling station location ${ }^{8}$ are sensible higher.

Another channel of influence regards the changes in the social networks after migration. This kind of change could influence the VT of both migrants and their home network (relatives, friends, neighbours, coworkers). Regarding the migrants, living in a new social context, defined by a disruption of social connections that results from moving abroad, reduces the social pressures to vote (Gerber, Green, and Larimer, 2008; Highton, 2000; Panagopoulos, 2011). The social theory of VT (Rolfe 2012) brings more explanation for the lower turnout of migrants. Viewing turnout decision "as a conditionally cooperative response to cooperative decisions made by friends, family, neighbours, and coworkers"

${ }^{5}$ In Denmark, most of voters are living at no more than 5 kilometers from a polling station (Bhatti, 2012). In US, the distance is generally below 10 miles for county level elections (Dyck and Gimpel, 2005), and half a mile in average for city level elections (Brady and McNulty, 2011).

6 Some empirical findings are quite relevant: an average increase of 0.3 miles to the polling station reduces the turnout by 3 percentage points (Brady and McNulty, 2011); for voters without a car the likelihood of voting drops from 0.664 at a distance of 0.01 miles to 0.418 at the median distance of 0.69 miles; if a car is available, voters are much less sensitive to changes in distance: the likelihood of voting drops from 0.444 to 0.392 over the same distance range (Haspel and Knotts, 2005); for those living 5 miles from a precinct site, nonvoting increases by 3.1 percent, and at 12 miles of distance, by 4.5 percent. (Dyck and Gimpel, 2005); an individual living 1-1.2 km from the polling station has a 4.9 percentage point lower probability of voting than a person living next to it (Bhatti, 2012).

7 For example, considering Romania, the number of polling stations from abroad was 170 in 1992, 119 in 1996, 152 in 2000, 153 in 2004, 221 in 2008, 294 in 2009, 306 in 2012 (BEC - INSSE). The average number of migrants per voting section from abroad lies between 9000 and 10000 , which is quite far from national average of around 1000 (own computations).

${ }^{8}$ Benefiting from a natural experiment, Brady and McNulty (2011) showed that the consolidation of voting precincts (change in polling place) increased the search costs, that in return caused a significant drop of turnout. 
(Rolfe, 2012: 4) and because migrants' social network is disrupted, VT is negatively affected. Regarding the network of migrants from the country of origin, one could expect also a change in VT. Consider the following scenario: one member of a social network migrates; the migrant is politically, socially and professionally more active (which is the case) in comparison to their social network; at the network level, the social pressures to participate socially, VT included, are decreasing; closer the connection between the migrant and a member of the network, less social pressure to participate upon that member; the consequence could be a decrease of turnout at network level.

As a direct consequence of all these factors I expect that turnout rate among transnational migrants will be much lower compared to national (internal) rates. To illustrate this statement, I present and compare the turnout rates in the Romanian national elections for the two types of polling stations: national (internal) and abroad (external) (Figure 2). On average, the internal turnout rate surpasses the external turnout rate by a factor of 13 (the variance is rather high, with a minimum of 4 and a maximum of 38).

Figure 2. Voter turnout rate in Romania: internal (national) vs. external (abroad)

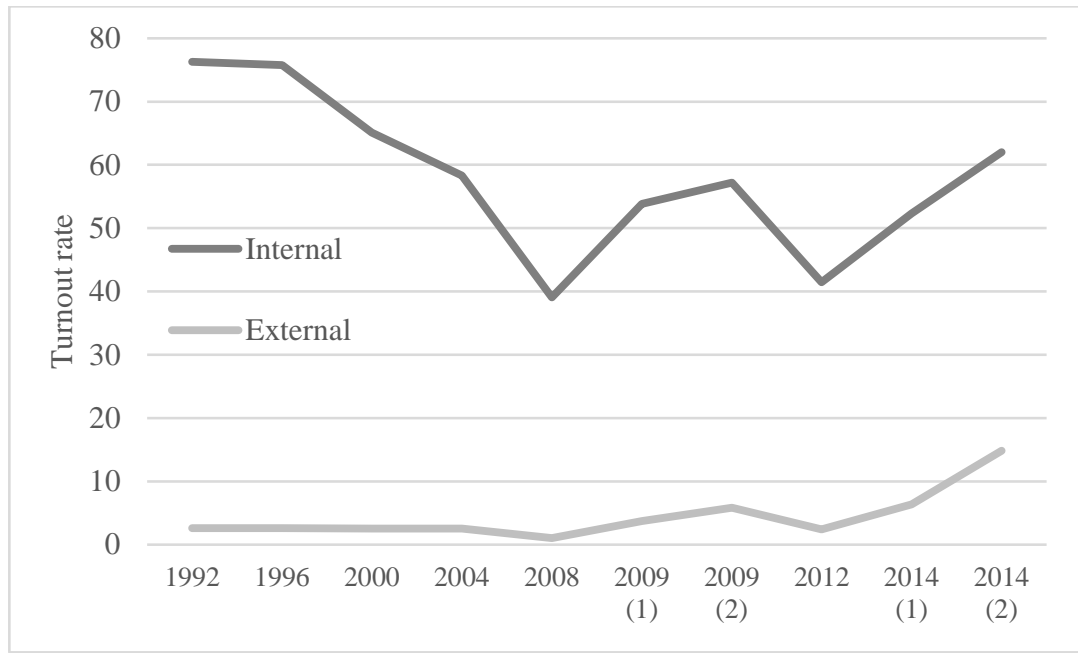

Source: Author's calculations based on WB and BEC Data on Parliamentary and Presidential elections: $1992-2004$

Parliamentary elections: 2008, 2012.

Presidential elections: 2009, 2014 (round 1 and 2). 


\section{Post-communist migration}

After the fall of communist regimes it seems as if a whole continent would have started moving towards the West (Black, Engbersen, Okólski, and Panţîru, 2010a). This move has not happened overnight, but in time, and after certain Western European states relaxed their restrictive entrance rules (such as easier access to travel in the Schengen Area, the introduction or extension of special employment programmes and a tacit tolerance of irregular residence or clandestine work) or after the enlargement of the European Union towards Central and Eastern Europe (CEE) (Black, Engbersen, Okólski, and Panţ̂ru, 2010b).

The estimation of the size of transnational migration and its dynamics is not an easy task. According to some studies (Mansoor and Quillin, 2006), around 3.2 million people migrated from ten CEE states to West Europe between 1989 and 2004. Shortly after the EU accession of new CEE member states (in 2004 and 2007), the number of transnational migrants increased a lot, even if official data underestimated it (Black et al., 2010b). The lack of reliable figures on migration is due to the inclusion of only registered workers without accounting for the large segment of unofficial labour migrants.

\section{Figure 3. Migrant population in former communist countries (1989-2012)}
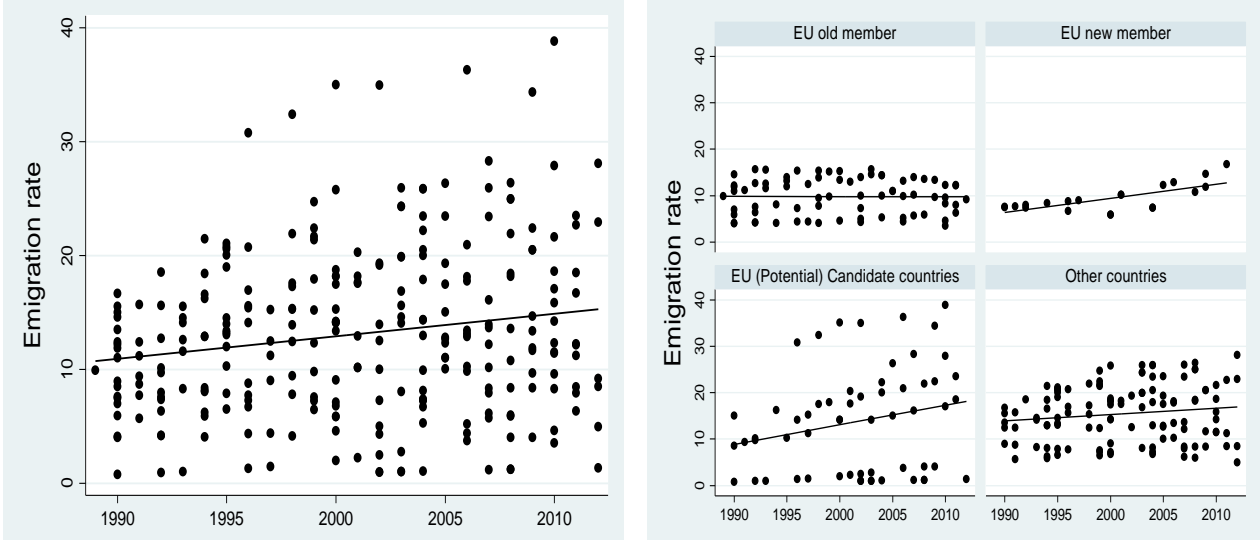

Source: Author's calculations based on WB Data.

Based on World Bank ${ }^{9}$ data related to the migration rate (the percentage of migrants from the total population) across countries, I have estimated the

\footnotetext{
${ }^{9}$ Using this source has the main advantage that includes migrant population estimates for all countries (origins and destinations), while Eurostat includes only data related to migration from one European Country to another. The problem is that data are not available for all years of interest. In order to fill the gaps, I imputed the missing values using one out of two regression models (linear or logistic, depending on data distribution shape).
} 
values of this indicator corresponding to a series of elections from 30 postcommunist countries for 1989-2012 (Figure 3). As one can observe, on average, the percentage of migrant population increased from around 10\% to $15 \%$ (from total population). Also, in the case of EU new and (potential) candidate members the increase is even larger. Based on these figures, one could expect a negative impact of migration on turnout.

\section{Data and method}

To answer the research question and test the hypotheses, I have considered 30 former communist countries ${ }^{10}$ and almost all presidential and parliamentary elections held in these countries between 1989 and 2012. The dataset has 272 cases (elections), with a minimum of four cases for Kosovo and a maximum of 13 for Poland. The source of turnout data was for most cases IDEA, but few cases were corrected or included from other sources when missing. For missing turnout figures and in order to control political variables, I have considered the following sources: Database of Political Institutions (DPI), Polity IV, Database on National Parliaments (IPU PARLINE), Psephos Adam Carr's Election Archive, European Election Database, ACE - The Electoral Knowledge Network, and Election Resources on the Internet. For socio-economic control variables I used: World Bank (WB), KOF Index of Globalization, Labour Force Survey (LFS), United Nations (UN), The United Nations Economic Commission for Europe (UNECE), The European Bank for Reconstruction and Development (EBRD), Freedom House (FH), and Central Intelligence Agency (CIA). In a few of the cases, for some data related to the beginning of the post-communist period, I have consulted a series of papers and books about post-communist transition (the full list is available upon request).

Generally, VT is measured in two ways: registered turnout (the number of voters divided by the number of registered voters) and voting-age-population (VAP) turnout (the number of voters divided by the number of citizens above the legal voting age). Both alternatives have advantages and disadvantages, and opting for one or the other depends on the researcher's interests. Also, both estimates can be affected by measurement errors. For example, if there are citizens that compose VAP who are not registered, VT will be overestimated; if there are citizens that have no possibility to vote (inaccurate electoral

\footnotetext{
10 Albania, Armenia, Azerbaijan, Belarus, Bosnia and Herzegovina, Bulgaria, Croatia, Czech Republic, Estonia, Georgia, Hungary, Kazakhstan, Kosovo, Kyrgyzstan, Latvia, Lithuania, Macedonia, Moldova, Montenegro, Poland, Romania, Russia, Serbia, Slovakia, Slovenia, Tajikistan, Turkmenistan, Ukraine, Uzbekistan, Yugoslavia, FR/Union of Serbia and Montenegro.
} 
registers: deaths, double listings, delinquents and mentally disturbed persons), VT will be underestimated. Because alternative measures such as turnout estimates based on voting-eligible-population proposed by McDonald and Popkin (2001) for the US are not available, I have conducted all the analyses using as a dependent variable each one of the turnout estimates at the time, in a similar way as Steiner (2010). ${ }^{11}$ As the two estimates are highly correlated (0.81), I expect the results to be similar.

Not all explanatory models of turnout decline presented above are appropriate for modelling VT change at aggregate (country) level. In some cases, explanatory variables are rather invariant, in other cases potential variables of interest are missing for most elections. Considering these constraints, I will retest the impact of the deteriorating economic and political conditions, electoral stakes, globalization and supra-national integration. Initially, I have included several macroeconomic measures such as GDP per capita, GDP growth, GDP growth one year before election, GDP growth in all the years after first election considered, and also unemployment rates and inflation (consumer prices). However, in models discussed in this paper I have only kept GDP growth one year before election. ${ }^{12}$ In order to measure political conditions defined as intra- and inter-party instability, I have considered the fractionalization index (the probability that two deputies picked at random from the legislature will be from different parties) and opposition fractionalization index (the probability that two deputies picked at random from among the opposition parties will be from different parties) as defined and computed by DPI. Electoral stakes have been measured as the importance of election, considering that presidential elections in presidential systems or parliamentary elections in parliamentary systems are more important (Pacek et al., 2009). Globalization was measured using the KOF overall index of globalization (Dreher, Gaston, and Martens, 2008). Integration in supranational political structures was measured by EU status in the election year: EU member and EU (potential) candidate.

Any explanatory model of turnout at country level should include control variables related to the political context (regime type, political institutions, and elections characteristics), economic context, and socio-demographic context. The most relevant models are presented below.

Indicators of the regime type (degree of democratization, polity fragmentation) are connected to VT (Geys, 2006; Kostadinova and Power, 2007). Former communist countries are closer to the democratic ideal in various degrees. Some countries can

\footnotetext{
11 Most studies that use turnout as dependent variable use one of the two measures (Geys, 2006).

12 I decided to skip these factors for reasons related to the ratio between the available sample size and the number of predictors and lack of statistically significant relations. Data source is World Bank and own calculations based on these data.
} 
be regarded as full democracies; others are rather autocracies. Democratic contexts may influence VT by allowing people to abstain without any concerns for potential penalties or by imposing citizens, more or less directly, to cast a vote. The fragmentation of polity varies from one country to the other. It can have an impact on VT, but I have no expectations about its magnitude and direction.

A second set of control variables are related to political institutions: the type of democracy (presidential, assembly-elected president, parliamentary), the type of electoral system (proportional or majoritarian), compulsory voting, the existence of a vote threshold, the number of chambers, and the size of districts. Even if there are questions and controversies about these relations (Blais, 2006), generally, VT it correlates positively with district size (Blais and Aarts, 2006; Kostadinova and Power, 2007), it is greater when voting is compulsory (Blais and Dobrzynska, 1998; Franklin, 2004; Geys, 2006; Stockemer and Scruggs, 2012), in unicameral systems (Fornos et al., 2004; Kostadinova and Power, 2007), in presidential systems (Stockemer and Calca, 2012), and in systems with proportional representation (Blais and Aarts, 2006; Blais and Dobrzynska, 1998; Geys, 2006). According to some studies (Endersby and Krieckhaus, 2008), the last finding is true only for fully democratic countries in systems with proportional representation, but other studies show that the relation between electoral disproportionality and VT increase in time even in the new democracies (Gallego, Rico, and Anduiza, 2012).

Electoral context is defined by characteristics like the type of election (parliamentary, presidentially, or both), the importance of election, margin of majority, the availability of voting from abroad, the possibility of voting by mail or on-line, and the extent of electoral fraud. Generally, concurrent and presidential elections attract a higher turnout (Geys, 2006; Kostadinova and Power, 2007; Kostelka, 2010). Margin of majority has systematic negative effect on VT (Geys, 2006; Stockemer and Scruggs, 2012), but sometimes the impact is rather small (Blais, 2006; Blais and Dobrzynska, 1998; Kostadinova, 2003).

Most studies have found that VT is higher in more developed countries (Blais and Dobrzynska, 1998; Fornos et al., 2004; Norris, 2002). Other measures of socio-economic development related with VT are human development (positive) (Pacek et al., 2009) and economic inequality (negative) (Solt, 2010). Other studies (Stockemer and Scruggs, 2012) failed to find a connection between income inequality and VT.

Socio-demographic context is defined by variables like population size, population density, percentage of the young population, percentage of the rural population, and distribution by religious affiliation. Because one vote counts less in larger countries, it is expected that the size of electoral body would be inversely 
related to VT (Blais, 2006; Geys, 2006; Steiner, 2010). Due to lower turnout rates among the younger electorate, a larger share of the young population has a negative impact on VT (Blais and Dobrzynska, 1998; Franklin, 2004). Population density and percentage of rural population are sometimes related to VT (Fornos et al., 2004; Kostadinova, 2003), but the findings are rather inconsistent (Blais, 2006; Geys, 2006). Compared to other religions, Islam followers seems to vote at lower rates (Bratton, Chu, and Lagos, 2010).

\section{Analyses and findings}

The dataset produced for the analyses is a cross-sectional panel. Due to serial auto-correlation, spatial auto-correlation, and panel heteroskedasticity, OLS regression is not appropriate (could produce smaller standard errors). In this case, one needs a statistical technique that allows for temporal and spatial auto-correlation and heteroskedasticity. Among the available techniques, the best choice seems to be Prais-Winsten regression models with heteroskedastic panels corrected standard errors; for example, the same technique was used by Pacek et al. (2009). Because I am interested in both the cross-country and the within-country effect of migration (and of other variables), I computed random-effects models. All statistical analyses were performed in Stata (13.1). I used the xtpcse procedure with the following options: correlation ar1 (specifies that, within panels, there is first-order auto-correlation AR(1) and that the coefficient of the AR(1) process is common to all the panels), hetonly (assume panel-level heteroskedastic errors), and np1 (weight panel-specific auto-correlations by panel sizes). ${ }^{13}$

As the regression results indicate (Appendix: Table $1 \mathrm{a}$ and $1 \mathrm{~b}$ ), in postcommunist states VT is declining between two consecutive national elections (election sequence variable, meaning election rank), in average, with 1.7-2.1 percentage points. The tendency is in agreement with findings from other studies (Kostadinova 2003; Kostadinova \& Power 2007), but, because my dataset includes more recent elections (have a more stable VT), the decline is not so steep.

Election sequence (time) accounts by itself for more than half of explained variance of VT (registered or VAP) decline. What is happening in this period to produce such a large decrease in turnout? The control variables reduce the impact of time and increase the explanatory power of the models

\footnotetext{
13 The results are quite robust to changing the options (PSAR instead AR or independent instead hetonly).
} 
(Appendix: Table 1a and 1b). Control variables with a positive impact on VT are autocracy level (in average, VT is $9-16$ percentage points higher in autocracies), assembly-elected president (0-5 points), simultaneous Parliamentary and Presidential elections (3-9 points), presidential elections (1-4 points), margins of majority (5-9 points), and proportion of rural population (0.2-0.4 percentage points for each percent of rural population). A negative effect is observed for polity fragmentation (in average, in countries with serious fragmentation VT is 2-6 points lower compared to countries with no fragmentation), population density (VT increases by 0.0-0.1 points for each percent of increase in rural population), and Islamic countries (VT is reduced by 4-12 points). Contrary to expectations, the possibility of external vote and the possibility to vote by mail or the Internet are correlated with a lower VT but, most probable, these rights were approved especially in low turnout countries or in countries with a significant decrease of turnout in order to boost the VT.

Deteriorating economic conditions (negative GDP growth compared to the year before the election) have a significant negative impact on registered turnout. Political conditions, measured as party fractionalization, have a negative impact too, opposition fractionalization being the most important factor (there is a 7-9 percentage points difference in VT corresponding to the difference between the minimum and the maximum values of party fractionalization). The "electoral stakes" hypothesis (Pacek et al., 2009) is supported by the analyses: the people are learning to identify which are the most important elections according to their national political context: on average, turnout in parliamentary elections in parliamentary system or presidential elections in presidential system is seven points higher. Even if overall globalization seems not to be related to VT, the level of integration in supra-national political structures has a statistically significant negative effect on VT: EU members have the lowest turnout, followed by (potential) EU candidate and third-countries which are not related to the EU have the highest turnouts. The models that are testing for the impact of deteriorating economic and political conditions and globalization-integration add just a little (1 percentage point) to the explained variance of VT decline. "Electoral stakes" hypothesis receives the largest support (the explained variance is increasing by 7-9 percentage points). Including these variables altogether does not change the picture too much. To sum up, the results support the conclusions from previous studies about factors associated with turnout decline in former communist countries (Bell, 2001; Hutcheson, 2004; Kostadinova, 2003; Kostadinova, 2009; Mason, 2003; Pacek, 1994; Pacek et al., 2009; Tworzecki, 2003) and strongly support the predominant impact of "electoral stakes" on VT decline.

None of the previous studies has included migration among factors related to turnout decrease. As outlined above, there are some important theoretical links between migration and VT. Based on these links one could 
expect a negative impact of migration on VT. To test this relation, I computed two regression models (including as controls the variables from previous models), one for each turnout type (registered and VAP). As one can see, the results are quite similar (Figure 4; Appendix: Table 1a and 1b).

Even if the explained variance does not change, migration rate has a significant negative effect on VT and, equally important, the impact of election sequence (election rank) is no more statistically significant. In both models, the regression coefficients associated with the measure of migration indicate that the impact of migration on VT is significant and quite large. An increase with one percentage point in migration rate lowers the turnout rate in average by around 0.4 percentage points. The same picture results from analyzing predicted values of turnout (Figure 4). Corresponding to the difference between the minimum and the maximum migration rate ( $0 \%$ to $30 \%)$, there is a decline in turnout (VAP or registered) of 12 percentage points.

Figure 4. The impact of migration rate on voter turnout (predictive margins with 95\% Cis; models with control variables included)
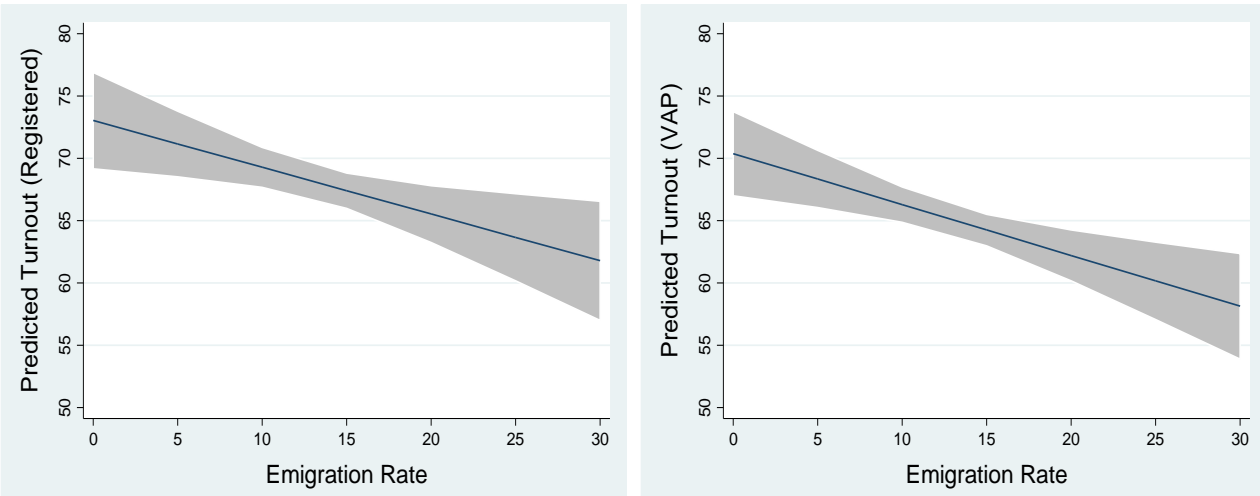

Source: Author's calculations.

In order to assess the robustness of the findings to sample selection, I estimated the final model considering only certain types of countries: EU member (present), EU candidate (present), non EU (present), EU member, EU member / candidate, European country, the extent of electoral fraud, and nonautocracy. As the results presented in Table $3 \mathrm{a}$ and $3 \mathrm{~b}$ from the Appendix indicate, the impact of migration on turnout is rather stable, with one exception: for the subset of EU countries, the impact of migration is positive in the case of VAP turnout. 
To assess the robustness of the findings to model specification (control variable combination and regression technique), I used "mrobust" procedure in Stata (Young and Kroeger, 2015). As control variables I included the same variables as those from the original model. As regression techniques I considered OLS, OLS with option vce (robust), robust OLS, fixed-effects and randomeffects (reg, rreg and xtreg from Stata). Robustness tests show that there is almost no uncertainty about the estimates (impact of migration on turnout). Tables 3a and 3b (Appendix) reports the two models (registered and VAP turnout) robustness results. There are no critical modelling choices, meaning none of the control variables or regression types have a high impact on estimates. Across the 1,310,720 possible models (combinations of 18 control variables and 5 regression techniques), the effect of migration rate is always negative, respectively negative and significant $97 \%$ of time (the few nonsignificant coefficients are all coming from the fixed-effects models - the marginal effect of this technique on estimates is -0.28 , respectively 0.10 ). The mean estimate of migration rate effect from all models is -0.66 , respectively -0.51 , and the total standard error (incorporating both sampling and modelling variance) is 0.29 , respectively 0.25 , yielding a robustness ratio of -2.23 , respectively -2.07 . Figure 5 shows the modelling distribution as a density graph of all calculated estimates; the vertical dashed line marks the 0.38 and 0.41 percent point estimates from Tables $1 \mathrm{a}$ and $1 \mathrm{~b}$. The majority of estimates are ranging from 0.4 to 0.8 for registered turnout, respectively 0.2 to 0.8 for VAP turnout. All these results indicate a strong, robust negative effect of migration on turnout.

Figure 5. Modelling distribution of the migration effect on turnout
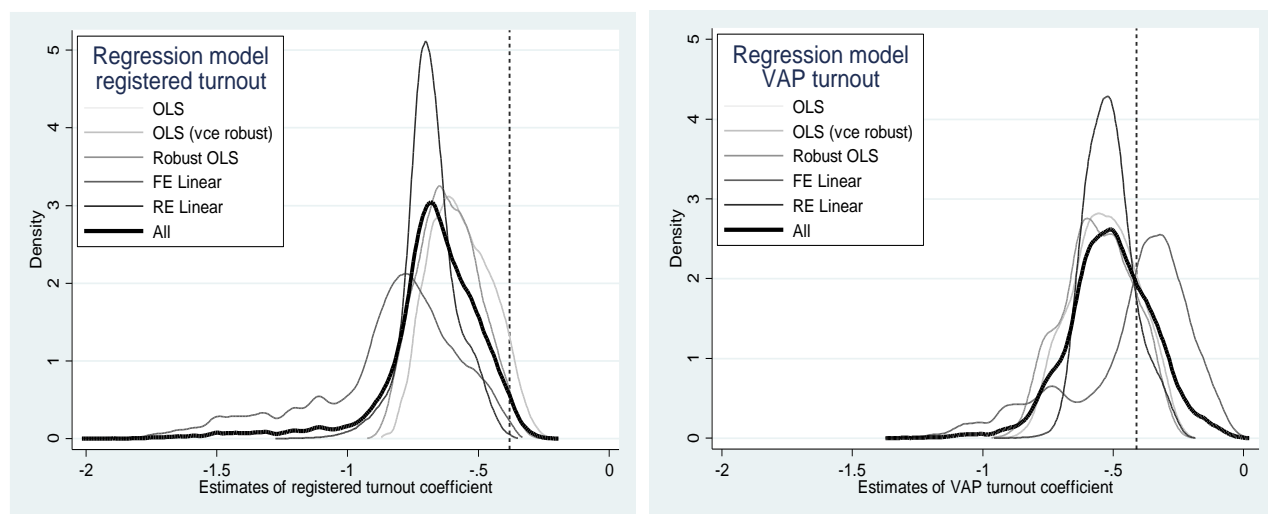

Source: Author's calculations.

Note: Kernel density graph of estimates from 1,310,720 models. See Tables 3a and 3b (Appendix) for more information about the distribution. The vertical line shows the preferred estimate from Tables 1a and 1b. As shown, these estimates are rather conservative related to the aggregate distribution of migration effect. 
Theoretically, the impact of migration rate on VT could differ across conditions. To check for this, I had run the main model including few potential interaction effects with the possibility of external voting, the possibility of Internet / mail voting, the extent of vote fraud, type of the country (European vs. non-European), and autocracy vs. non-autocracy (Appendix: Table 4a and 4b, Figure A6). Most interaction effects are low, not statistically significant and inconsistent, but two, both related to registered turnout: the impact of migration rate on VT is smaller in countries that allow for external vote or are non-European.

\section{Conclusions and implications}

The analyses presented here indicate that economic and political conditions, "electoral stakes", economic globalization and supra-national integration are closely related to turnout decline in former communist countries. Among these hypotheses, "electoral stakes" hypothesis (people are learning which elections are more important) receives the strongest support. The main finding of this paper is that migration contributes to a large extent to turnout decline in former communist countries. Related to this main finding, one can identify implications for several areas of research: democratic theory, citizens' political rights, election results, and turnout puzzles.

The link between migration and turnout, seen as a key element of democracy, can be described as follows. Most of transnational migrants remain citizens of their countries of origin; their abstention reduced the legitimacy of elections because fewer people vote and because the interests of a specific social category, i.e. transnational migrants, are underrepresented; migrants' decisions to remain abroad or to return in their home countries largely depend on their sentiments of belonging to their countries of origin and also on how major national institutions represent their interests. A sizeable segment of transnational migrants keep contact with their countries of origin; some of them plan to return home, they buy houses and plan to start a business upon their return; many of them send money to their relatives, etc. Because transnational migrants act like small investors, they expect to be involved in public policy decisions. In their destination countries, migrants have contact, directly or mediated, with old and consolidated democratic cultures, they see how established democracies work, how state institutions respond to citizens' demands, and how political decisions are made. Consequently, their political culture changes, they start questioning the functioning of democratic institutions in their countries of origin, and they share their experiences with their relatives from home. In this way, migrants influence democratic processes from their home countries. 
In two cases (Albania and Armenia), voting from abroad is not allowed by electoral rules (Ellis, Wall, International Institute for, Electoral, \& Instituto Federal 2007). With some exceptions (Bosnia and Herzegovina, Estonia, Latvia, Lithuania, Poland, and Slovenia), voting from abroad is possible, but only in person. Allowing different forms of external voting (postal, e-voting) could raise the participation of migrants by reducing the cost (time and money) of voting. Even if, probably, turnout increase will not last, as it happened in the case of Estonia (Ellis, et al., 2007: 228), it is important for democracy that different categories of citizens have the same voting rights, they are equally represented, and that they contribute equally to the legitimacy of elected bodies.

Another argument about the importance of turnout is related to the fact that, in some of the new democracies, the referendums are considered valid only if a specific threshold is fulfilled (30\% or $50 \%$ plus 1 of the registered citizens cast their votes). In circumstances like this, estimating the denominator (the number of citizens with voting rights), becomes sometimes a major political issue (see the presidential impeachment referendum held in Romania in 2012) given its serious implications. If migrants are included in the denominator, the number of voters will need to be larger in order to validate the referendum.

In some circumstances, voters from abroad could change the winner of the elections. This happened in the 2009 Romanian Presidential elections, ${ }^{14}$ when Mircea Geoană received few more votes from domestic voters but lost the contest after Traian Băsescu surpassed him by winning more votes from abroad. Even more, voters from abroad could influence the voting choice of their relatives and close friends from their countries of origin. This was the case in 2014 Romanian Presidential elections, organized under the Victor Ponta as prime minister at the time, but also one of the competitors for presidency. The government did not take any real measure in order to facilitate the voting process in the diaspora, such as to increase the number of polling stations from abroad, for example. In some cases, polling stations were situated at hundreds of kilometres from the Romanian communities abroad. The voting process was in general slow and rigid, and sometimes the polling stations had insufficient staff and voting stamps. Consequently, at both election rounds, in many voting places from abroad (from big cities especially), thousands of voters waited in queues for many hours, and many of them could not even vote before the closing of polls. In some cases, voters that were unable to vote protested against the closing of the polling stations and local police was called by the embassy staff to disperse the crowd. In the context of these problems, and in order to preserve the voting rights for Romanian citizens living abroad, the electoral legislation could have

\footnotetext{
14 The case of Romania is relevant because of his high rate of migration.
} 
allowed mail and / or e-voting, but this did not happen. This way, the cost of voting (time and money) could be reduced and a larger share of the diaspora could cast a vote in the future elections. Adopting new methods of voting can raise security and other issues, but new democracies can learn from Western experiences in this respect.

Furthermore, these findings could add to the debates about the dynamic of turnout and the size of turnout decline, contribute at explaining the differences in turnout level and trend among East European countries, and also between Eastern and Western democracies. By including migration in multivariate models of VT (or by using turnout rates adjusted by migration rate), scholars could avoid the problem of omitting explanatory variables, better identify significant effects and evaluate their relative importance, or explain more accurately time associated changes in variances and relationships. Also, the link between citizens' transnational migration and their turnout could explain some (apparent) turnout puzzles like: Why is turnout declining if educational level and partisanship were increasing? Why are the citizens of Eastern Europe less likely to vote than those of Western Europe (Karp and Milazzo, 2015; Kostelka, 2014), even after controlling for a series of variables but migration? Considering the findings of this paper, the aforementioned puzzles can be solved by including into the explanatory models of turnout, besides education, partisanship or other usual explanatory and control variables, the rate of citizens' transnational migration as well.

\section{REFERENCES}

Aldrich, J. H. (1993). Rational Choice and Turnout. American Journal of Political Science, 37(2): 246-278.

Bell, J. (2001). The political economy of reform in post-communist Poland. Cheltenham, UK; Northampton, MA: E. Elgar.

Bernhagen, P., \& Marsh, M. (2007). Voting and Protesting: Explaining Citizen Participation in Old and New European Democracies. Democratization, 14(1): 44-72.

Bhatti, Y. (2012). Distance and Voting: Evidence from Danish Municipalities. Scandinavian Political Studies, 35(2): 141-158.

Black, R., Engbersen, G., Okólski, M., \& Panţîru, C. (2010a). A continent moving west? EU enlargement and labour migration from Central and Eastern Europe. Amsterdam; Manchester: Amsterdam University Press; Manchester University Press.

Black, R., Engbersen, G., Okólski, M., \& Panţîru, C. (2010b). Introduction: Working out a way from East to West: EU enlargement and labour migration from Central and Eastern Europe. In R. Black, G. Engbersen, M. Okólski \& C. Panţîru (Eds.), A continent moving west? EU enlargement and labour migration from Central and Eastern Europe. Amsterdam: Amsterdam University Press. 
Blais, A. (2000). To Vote or not to Vote: The Merits and Limits of Rational Choice Theory. Pittsburgh: University of Pittsburgh Press.

Blais, A. (2006). What Affects Voter Turnout? Annual Review of Political Science, 9(1): 111-125.

Blais, A., \& Aarts, K. (2006). Electoral Systems and Turnout. Acta Politica, 41(2): 180196.

Blais, A., \& Dobrzynska, A. (1998). Turnout in electoral democracies. European Journal of Political Research, 33(2): 239-261.

Brady, H. E., \& McNulty, J. E. (2011). Turning Out to Vote: The Costs of Finding and Getting to the Polling Place. [Article]. American Political Science Review, 105(1): 115-134.

Bratton, M., Chu, Y.-h., \& Lagos, M. (2010). Who Votes? Implications for New Democracies. Taiwan Journal of Democracy, 6(1): 107-136.

Czesnik, M. (2006). Voter turnout and democratic legitimacy in Central Eastern Europe. Polish Sociological Review, 156: 449-470.

Dahl, R. A. (1998). On democracy. New Haven: Yale University Press.

Downs, A. (1957). An economic theory of democracy. New York: Harper.

Dreher, A., Gaston, N., \& Martens, W. J. M. (2008). Measuring globalisation gauging its consequences. http://public.eblib.com/choice/publicfullrecord.aspx?p=416977 (Accessed: November 2017).

Dyck, J. J., \& Gimpel, J. G. (2005). Distance, turnout, and the convenience of voting. Social Science Quarterly, 86(3): 531-548.

Ellis, A., Wall, A., International Institute for, D., Electoral, A., \& Instituto Federal, E. (2007). Voting from abroad: the International IDEA handbook. Stockholm, Sweden; Mexico City, Mexico: International IDEA; Federal Electoral Institute of Mexico.

Endersby, J. W., \& Krieckhaus, J. T. (2008). Turnout around the globe: The influence of electoral institutions on national voter participation, 1972-2000. Electoral Studies, 27(4): 601-610.

Fauvelle-Aymar, C., \& Stegmaier, M. (2008). Economic and political effects on European Parliamentary electoral turnout in post-communist Europe. Electoral Studies, 27(4): 661-672.

Fornos, C. A., Power, T. J., \& Garand, J. C. (2004). Explaining voter turnout in latin America, 1980 to 2000. Comparative Political Studies, 37(8): 909-940.

Franklin, N. M. (2004). Voter Turnout and the Dynamics of Electoral Competition in Established Democracies since 1945. Cambridge: Cambridge University Press.

Gallego, A., Rico, G., \& Anduiza, E. (2012). Disproportionality and voter turnout in new and old democracies. Electoral Studies, 31(1): 159-169.

Gerber, A. S., Green, D. P., \& Larimer, C. W. (2008). Social pressure and voter turnout: Evidence from a large-scale field experiment. American Political Science Review, 102(1): 33-48.

Geys, B. (2006). Explaining voter turnout: A review of aggregate-level research. Electoral Studies, 25(4): 637-663. 
Hadjar, A., \& Beck, M. (2010). Who does not participate in elections in Europe and why is this? A multilevel analysis of social mechanisms behind non-voting. European Societies, 12(4): 521-542.

Haspel, M., \& Knotts, H. G. (2005). Location, location, location: Precinct placement and the costs of voting. Journal of Politics, 67(2): 560-573.

Highton, B. (2000). Residential mobility, community mobility, and electoral participation. Political Behavior, 22(2): 109-120.

Howard, M. M. (2003). Why post-communist citizens do not join voluntary organizations. In G. Badescu \& E. M. Uslaner (Eds.), Social capital and the transition to democracy. London: Routledge.

Huntington, S. P. (1991). The third wave: democratization in the late twentieth century. Norman: University of Oklahoma Press.

Hutcheson, D. S. (2004). Protest and disengagement in the Russian federal elections of 2003-04. Perspectives on European Politics and Society, 5(2): 305-330.

Inglehart, R., \& Catterberg, G. (2002). Trends in Political Action: The Developmental Trend and the Post-Honeymoon Decline. International Journal of Comparative Sociology, 43(3-5): 300-316.

Karp, J. A., \& Milazzo, C. (2015). Democratic Scepticism and Political Participation in Europe. Journal of Elections, Public Opinion and Parties, 25(1): 97-110.

Kostadinova, T. (2003). Voter turnout dynamics in post-Communist Europe. European Journal of Political Research, 42(6): 741-759.

Kostadinova, T. (2009). Abstain or Rebel: Corruption Perceptions and Voting in East European Elections. Politics \& Policy, 37(4): 691-714.

Kostadinova, T., \& Power, T. J. (2007). Does Democratization Depress Participation? Voter Turnout in the Latin American and Eastern European Transitional Democracies. Political Research Quarterly, 60(3): 363-377.

Kostelka, F. (2010). The Turnout Decline in the Post-Communist Members States of the EU: A Multicausal Explanation. The 3rd ECPR Graduate Conference. Dublin, 30th August - 1st September 2010.

Kostelka, F. (2014). The State of Political Participation in Post-Communist Democracies: Low but Surprisingly Little Biased Citizen Engagement. Europe-Asia Studies, 66(6): 945-968.

Lafleur, J. M., \& Chelius, L. C. (2011). Assessing Emigrant Participation in Home Country Elections: The Case of Mexico's 2006 Presidential Election. International Migration, 49(3): 99-124.

Lâopez Pintor, R., Gratschew, M., Adåimåi, J. a.-D., \& International Institute for Democracy and Electoral Assistance. (2002). Voter turnout since 1945: A global report. Stockholm, Sweden: International Institute for Democracy and Electoral Assistance.

Lijphart, A. (1997). Unequal Participation: Democracy's Unresolved Dilemma. American Political Science Review, 91(1): 1-14.

Lijphart, A. (1998). The problem of low and unequal voter turnout - and what we can do about it. Wien: Institut für Höhere Studien. 
Lijphart, A. (2000). Democracy in the twenty-first century: Can we be optimistic? Wassenaar, The Netherlands: Netherlands Institute for Advanced Study in the Humanities and Social Sciences.

Mansoor, A. M., \& Quillin, B. (2006). Migration and remittances Eastern Europe and the Former Soviet Union. http://public.eblib.com/EBLPublic/

PublicView.do?ptiID=459583 (Accessed: November 2017).

Mason, D. S. (2003). Fairness Matters: Equity and the Transition to Democracy. World Policy Journal, 20(4): 48-56.

McDonald, P. M., \& Popkin, S. L. (2001). The myth of the vanishing voter. American Political Science Review, 95(4): 963-974.

McNulty, J. E., Dowling, C. M., \& Ariotti, M. H. (2009). Driving Saints to Sin: How Increasing the Difficulty of Voting Dissuades Even the Most Motivated Voters. Political Analysis, 17(4): 435-455.

Niemi, R. G. (1976). Costs of Voting and Nonvoting. Public Choice, 27(3), 115-119.

Norris, P. (1999). Critical citizens: global support for democratic government. Oxford: Oxford University Press.

Norris, P. (2002). Democratic phoenix: reinventing political activism. Cambridge: Cambridge University Press.

Pacek, A. C. (1994). Macroeconomic conditions and electoral-politics in East-CentralEurope. American Journal of Political Science, 38(3): 723-744.

Pacek, A. C., Pop-Eleches, G., \& Tucker, J. A. (2009). Disenchanted or Discerning: Voter Turnout in Post-Communist Countries. Journal of Politics, 71(2): 473-491.

Panagopoulos, C. (2011). Social pressure, surveillance and community size: Evidence from field experiments on voter turnout. Electoral Studies, 30(2): 353-357.

Patterson, T. E. (2002). The vanishing voter: public involvement in an age of uncertainty (1st ed.). New York: Alfred A. Knopf: Distributed by Random House.

Radcliff, B. (1992). The Welfare-State, Turnout, and the Economy - A Comparative Analysis. . American Political Science Review, 86(2): 444-454.

Rolfe, M. (2012). Voter turnout: a social theory of political participation. Cambridge: Cambridge University Press.

Rose, R. (1995). Mobilizing Demobilized Voters in Post-Communist Societies. Party Politics, 1(4): 549-563.

Solt, F. (2010). Does Economic Inequality Depress Electoral Participation? Testing the Schattschneider Hypothesis. Political Behavior, 32(2): 285-301.

Steiner, N. D. (2010). Economic globalization and voter turnout in established democracies. Electoral Studies, 29(3): 444-459.

Stockemer, D., \& Calca, P. (2012). Presidentialism and Voter Turnout in Legislative Elections. Parliamentary Affairs.

Stockemer, D., LaMontagne, B., \& Scruggs, L. (2013). Bribes and ballots: The impact of corruption on voter turnout in democracies. International Political Science Review, 34(1): 74-90.

Stockemer, D., \& Scruggs, L. (2012). Income inequality, development and electoral turnout - New evidence on a burgeoning debate. Electoral Studies, 31(4), 764773. 
Sundström, A., \& Stockemer, D. (2013). Quality of government affect voter turnout in the European regions. QoG Working Paper Series.

Teixeira, R. A. (1992). The Disappearing American Voter. Washington DC: Brookings.

Turner, A. W. (1993). Postauthoritarian Elections: Testing Expectations about "First" Elections. Comparative Political Studies Comparative Political Studies, 26(3): 330-349.

Tworzecki, H. (2003). Learning to choose: electoral politics in East-Central Europe. Stanford: Stanford University Press.

Verba, S., Schlozman, K. L., \& Brady, H. E. (1995). Voice and equality: civic voluntarism in American politics. Cambridge: Harvard University Press.

Wattenberg, P. M. (2002). Where Have All the Voters Gone? Cambridge: Harvard University Press.

White, S., \& McAllister, I. (2004). Dimensions of disengagement in post-communist Russia. Journal of Communist Studies and Transition Politics, 20(1): 81-97.

White, S., \& McAllister, I. (2007). Turnout and representation bias in post-communist Europe. Political Studies, 55(3): 586-606.

Young, C. \& Holsteen, K. (2015). Model Uncertainty and Robustness: A Computational Framework for Multimodel Analysis. Sociological Methods \& Research, first published on October 23, 2015. 


\section{Appendix}

Table 1a. Explaining turnout decline in post-communist countries
(registered turnout) $\dagger$

\begin{tabular}{|c|c|c|c|c|c|c|c|c|}
\hline $\begin{array}{l}\text { Independent } \\
\text { variables }\end{array}$ & Time & Controls & $\begin{array}{l}\text { Economic } \\
\text { conditions }\end{array}$ & $\begin{array}{c}\text { Political } \\
\text { conditions }\end{array}$ & $\begin{array}{c}\text { Electoral } \\
\text { stakes }\end{array}$ & $\begin{array}{c}\text { Globaliza } \\
\text { tion }\end{array}$ & All & $\underset{\text { Migration }}{\text { All + }}$ \\
\hline Election Sequence & $-2.11^{* *}$ & $-1.67^{* *}$ & $-1.58 * *$ & $-1.72^{* *}$ & $-1.72 * *$ & $-0.84^{*}$ & $-0.85^{*}$ & -0.50 \\
\hline $\begin{array}{l}\text { Polity } \\
\text { Fragmentation }\end{array}$ & & $-3.12^{* *}$ & $-2.16+$ & $-2.77^{*}$ & $-3.39^{* *}$ & $-3.69 * *$ & $-2.83^{* *}$ & -1.66 \\
\hline Polity IV: Autocracy & & $11.56^{* *}$ & $13.03^{* *}$ & $12.16^{* *}$ & $13.06^{* *}$ & $12.22^{* *}$ & $16.01^{* *}$ & $13.49^{* *}$ \\
\hline $\begin{array}{l}\text { Assembly-Elected } \\
\text { President }\end{array}$ & & $4.92^{*}$ & $3.86+$ & $3.58+$ & $4.96^{*}$ & $4.23 *$ & 2.00 & 1.85 \\
\hline $\begin{array}{l}\text { Vote Threshold } \\
(\log +1)\end{array}$ & & -4.22 & -2.75 & -3.56 & -3.14 & -2.95 & 0.14 & 0.01 \\
\hline $\begin{array}{l}\text { Sim. Parl. \& Pres. } \\
\text { Elections }\end{array}$ & & 3.50 & 2.85 & 3.81 & $6.34^{*}$ & 3.38 & $5.67^{*}$ & $6.59 *$ \\
\hline $\begin{array}{l}\text { Presidential } \\
\text { Election }\end{array}$ & & $2.82^{* *}$ & $2.87^{* *}$ & $3.05^{* *}$ & 1.37 & $2.74^{* *}$ & $1.55+$ & 1.27 \\
\hline Margin of Majority & & $9.22^{* *}$ & $8.83^{*}$ & 6.26 & $7.01^{*}$ & $7.17^{*}$ & 4.67 & 4.81 \\
\hline $\begin{array}{l}\text { External Vote } \\
\text { Possible }\end{array}$ & & -3.20 & $-3.60+$ & -3.33 & -2.02 & $-3.40+$ & $-3.34+$ & -3.00 \\
\hline $\begin{array}{l}\text { Postal or E-Voting } \\
\text { Possible }\end{array}$ & & -2.51 & -3.04 & -2.13 & -2.96 & -1.33 & -2.22 & -1.60 \\
\hline Vote Fraud & & 1.65 & 2.82 & 0.49 & 1.66 & 0.17 & 0.29 & 0.77 \\
\hline Population density & & $-0.10^{* *}$ & $-0.11^{* *}$ & $-0.10^{* *}$ & $-0.10^{* *}$ & $-0.09 * *$ & $-0.11^{* *}$ & $-0.09 * *$ \\
\hline \% Youth (15-34) Pop. & & 0.49 & 0.58 & 0.50 & 0.34 & 0.30 & 0.23 & 0.18 \\
\hline \% Rural Pop. & & $0.33^{* *}$ & $0.35^{* *}$ & $0.33^{* *}$ & $0.41^{* *}$ & $0.31^{* *}$ & $0.42^{* *}$ & $0.29^{*}$ \\
\hline Islam Country & & $-11.17^{* *}$ & $-12.23^{* *}$ & $-10.88^{* *}$ & $-11.79 * *$ & $-9.91 * *$ & $-11.84^{* *}$ & $-7.67^{*}$ \\
\hline $\begin{array}{l}\text { Non-European } \\
\text { Country }\end{array}$ & & -1.41 & -2.90 & -1.37 & 0.15 & $-5.18+$ & $-4.96^{*}$ & $-4.02+$ \\
\hline GDP Growth (t-1) & & & $-0.13^{* *}$ & & & & $-0.13^{* *}$ & $-0.11^{*}$ \\
\hline $\begin{array}{l}\text { Fractionalization } \\
\text { Index }\end{array}$ & & & & -1.46 & & & 1.92 & 3.67 \\
\hline $\begin{array}{l}\text { Opposition Fract. } \\
\text { Index }\end{array}$ & & & & $-7.30^{*}$ & & & $-6.46^{*}$ & $-6.63^{*}$ \\
\hline $\begin{array}{l}\text { Election Importance } \\
\text { Hightt }\end{array}$ & & & & & $6.94^{* *}$ & & $6.76^{* *}$ & $6.90^{* *}$ \\
\hline $\begin{array}{l}\text { EU Status - } \\
\text { Member }+\dagger \dagger\end{array}$ & & & & & & $-6.07+$ & $-6.95^{*}$ & $-7.29^{* *}$ \\
\hline $\begin{array}{l}\text { EU Status - } \\
\text { Candidate }+\dagger \dagger\end{array}$ & & & & & & $-6.31^{* *}$ & $-5.53^{* *}$ & $-5.14^{* *}$ \\
\hline $\begin{array}{l}\text { Overall Globalization } \\
\text { Index }\end{array}$ & & & & & & -0.15 & $-0.16+$ & $-0.24^{* *}$ \\
\hline Migration rate & & & & & & & & $-0.38^{* *}$ \\
\hline Constant & & $55.97^{* *}$ & $52.68^{* *}$ & $63.15^{* *}$ & $53.84^{* *}$ & $70.42^{* *}$ & $68.65^{* *}$ & $78.96^{* *}$ \\
\hline$R^{2}$ & 0.57 & 0.64 & 0.64 & 0.65 & 0.72 & 0.66 & 0.74 & 0.74 \\
\hline$N$ & 272 & 272 & 272 & 272 & 272 & 272 & 272 & 272 \\
\hline
\end{tabular}

Regression coefficients (xtpcse); 30 countries; 272 cases (elections); $+p<0.1{ }^{*} p<0.05 ;{ }^{* *} p<0.01$

$\uparrow$ The initial model included some other independent variables which were excluded from the final model for reasons related to low sample size, too many predictors and non-significance (Freedom House Index, Political System Presidential, Proportional Representation, Unicameralism, District Magnitude Candidates (log), Human Development Index, Gini Index, GDP Per Capita, PPP (constant 2005 int. \$), GDP Growth (annual \%) related to the first year in the dataset (sqrt*10), Unemployment (\% of total labor force), Inflation, consumer prices (log+10)).

†† Parliamentary Elections in Parliamentary System or Presidential Elections in Presidential System.

†† at the time of elections. 


\section{Table 1b. Explaining turnout decline in post-communist countries (VAP turnout) $\dagger$}

\begin{tabular}{|c|c|c|c|c|c|c|c|c|}
\hline $\begin{array}{l}\text { Independent } \\
\text { variables }\end{array}$ & Time & Controls & $\begin{array}{l}\text { Economic } \\
\text { conditions }\end{array}$ & $\begin{array}{l}\text { Political } \\
\text { conditions }\end{array}$ & $\begin{array}{l}\text { Electoral } \\
\text { stakes }\end{array}$ & $\begin{array}{l}\text { Globaliza } \\
\text { tion }\end{array}$ & All & $\begin{array}{c}\text { All + } \\
\text { Migration }\end{array}$ \\
\hline Election Sequence & $-1.71^{* *}$ & $-1.09^{* *}$ & $-1.06^{* *}$ & $-1.16^{* *}$ & $-1.15^{* *}$ & -0.49 & -0.49 & -0.07 \\
\hline $\begin{array}{l}\text { Polity } \\
\text { Fragmentation }\end{array}$ & & $-5.30^{* *}$ & $-4.93^{* *}$ & $-5.19^{* *}$ & $-5.36^{* *}$ & $-5.88^{* *}$ & $-5.61^{* *}$ & $-4.43^{* *}$ \\
\hline Polity IV: Autocracy & & $9.19 * *$ & $9.78^{* *}$ & $10.59^{* *}$ & $10.37^{* *}$ & $10.11^{* *}$ & $13.42^{* *}$ & $10.57^{* *}$ \\
\hline $\begin{array}{l}\text { Assembly-Elected } \\
\text { President }\end{array}$ & & 1.68 & 1.17 & 0.84 & 1.61 & 1.21 & -0.19 & -0.40 \\
\hline $\begin{array}{l}\text { Vote Threshold (log } \\
+1 \text { ) }\end{array}$ & & $-7.08^{* *}$ & $-6.48^{*}$ & $-5.72^{*}$ & $-6.19 *$ & $-5.83^{*}$ & -2.98 & -3.10 \\
\hline $\begin{array}{l}\text { Sim. Parl. \& Pres. } \\
\text { Elections }\end{array}$ & & $5.86^{*}$ & $5.54+$ & $6.72 *$ & $8.63^{* *}$ & $5.82 *$ & $8.72^{* *}$ & $9.82^{* *}$ \\
\hline Presidential Election & & $3.52^{* *}$ & $3.57^{* *}$ & $3.74^{* *}$ & $2.15^{*}$ & $3.42^{* *}$ & $2.25^{*}$ & $1.96^{*}$ \\
\hline Margin of Majority & & $7.37^{*}$ & $7.25^{*}$ & $7.50+$ & $5.70+$ & $6.21+$ & $7.17+$ & $7.75^{*}$ \\
\hline External Vote Possible & & $-4.85^{*}$ & $-4.95^{*}$ & $-5.35^{* *}$ & $-3.66+$ & $-4.86^{*}$ & $-4.91^{*}$ & $-4.56^{*}$ \\
\hline $\begin{array}{l}\text { Postal or E-Voting } \\
\text { Possible }\end{array}$ & & $-9.06^{* *}$ & $-9.23^{* *}$ & $-8.60^{* *}$ & $-9.56^{* *}$ & $-7.84^{* *}$ & $-8.21^{* *}$ & $-7.45^{* *}$ \\
\hline Vote Fraud & & 2.81 & $3.24+$ & 1.73 & 2.91 & 1.76 & 1.21 & 1.69 \\
\hline Population density & & 0.01 & 0.00 & 0.01 & 0.00 & 0.01 & 0.01 & 0.03 \\
\hline \% Youth (15-34) Pop. & & -0.31 & -0.28 & -0.29 & -0.38 & -0.50 & -0.56 & $-0.66+$ \\
\hline \% Rural Pop. & & $0.20 *$ & $0.21^{*}$ & $0.20^{*}$ & $0.25^{*}$ & $0.20 *$ & $0.27^{* *}$ & 0.13 \\
\hline Islam Country & & -5.14 & -5.49 & -5.21 & -5.69 & -4.44 & $-5.68+$ & -1.24 \\
\hline $\begin{array}{l}\text { Non-European } \\
\text { Country }\end{array}$ & & $-4.48^{*}$ & $-5.05^{*}$ & $-3.88+$ & -3.28 & $-6.69 * *$ & $-5.65^{*}$ & $-4.45^{*}$ \\
\hline GDP Growth (t-1) & & & -0.05 & & & & -0.05 & -0.03 \\
\hline $\begin{array}{l}\text { Fractionalization } \\
\text { Index }\end{array}$ & & & & 4.20 & & & $7.39^{*}$ & $9.83^{* *}$ \\
\hline $\begin{array}{l}\text { Opposition Fract. } \\
\text { Index }\end{array}$ & & & & $-9.27 * *$ & & & $-8.42^{* *}$ & $-8.42^{* *}$ \\
\hline $\begin{array}{l}\text { Election Importance } \\
\text { High } \dagger\end{array}$ & & & & & $6.51^{* *}$ & & $6.40^{* *}$ & $6.55^{* *}$ \\
\hline $\begin{array}{l}\text { EU Status - Member } \\
+\dagger \dagger\end{array}$ & & & & & & $-5.89^{*}$ & $-6.82^{* *}$ & $-7.21^{* *}$ \\
\hline $\begin{array}{l}\text { EU Status - } \\
\text { Candidate }+\dagger \dagger\end{array}$ & & & & & & $-3.84+$ & $-3.22+$ & -2.57 \\
\hline $\begin{array}{l}\text { Overall Globalization } \\
\text { Index }\end{array}$ & & & & & & -0.09 & -0.12 & $-0.23^{* *}$ \\
\hline Migration rate & & & & & & & & $-0.41^{* *}$ \\
\hline Constant & & $77.92 * *$ & $76.88^{* *}$ & $79.25^{* *}$ & $74.61^{* *}$ & $87.82 * *$ & $83.04^{* *}$ & $95.14^{* *}$ \\
\hline$R^{2}$ & 0.52 & 0.57 & 0.57 & 0.57 & 0.66 & 0.59 & 0.67 & 0.67 \\
\hline$N$ & 272 & 272 & 272 & 272 & 272 & 272 & 272 & 272 \\
\hline
\end{tabular}

Regression coefficients (xtpcse); 30 countries; 272 cases (elections); $+p<0.1{ }^{*} p<0.05$; ${ }^{* *} p<0.01$

$\dagger$ The initial model included some other independent variables which were excluded from the final model for reasons related to low sample size, too many predictors and non-significance (Freedom House Index, Political System - Presidential, Proportional Representation, Unicameralism, District Magnitude Candidates (log), Human Development Index, Gini Index, GDP Per Capita, PPP (constant 2005 int. \$), GDP Growth (annual \%) related to the first year in the dataset (sqrt * 10), Unemployment (\% of total labor force), Inflation, consumer prices $(\log +10)$ ).

†† Parliamentary Elections in Parliamentary System or Presidential Elections in Presidential System. †† at the time of elections. 


\section{Table 2a. Robustness checks: Explaining turnout decline in post-communist countries (registered turnout) $\dagger$}

\begin{tabular}{|c|c|c|c|c|c|c|c|c|c|}
\hline $\begin{array}{l}\text { Independent } \\
\text { variables }\end{array}$ & All cases & $\begin{array}{c}\text { EU } \\
\text { member } \\
\text { (present) }\end{array}$ & $\begin{array}{c}\text { EU } \\
\text { candidate } \\
\text { (present) }\end{array}$ & $\begin{array}{c}\text { Non EU } \\
\text { (present) }\end{array}$ & $\begin{array}{c}\text { EU } \\
\text { member } \\
+\dagger \dagger\end{array}$ & $\begin{array}{c}\text { EU } \\
\text { member / } \\
\text { candidate } \\
+\dagger \dagger\end{array}$ & $\begin{array}{c}\text { European } \\
\text { country }\end{array}$ & $\begin{array}{l}\text { Electoral } \\
\text { fraud }\end{array}$ & $\begin{array}{l}\text { Non- } \\
\text { Autoc- } \\
\text { racy }\end{array}$ \\
\hline Election Sequence & -0.50 & $-1.39 *$ & -0.07 & $1.20+$ & -0.74 & -0.70 & -0.35 & -1.57 & -0.47 \\
\hline $\begin{array}{l}\text { Polity Fragmentation } \\
\text { Polity IV-Autosy }\end{array}$ & $\begin{array}{l}-1.66 \\
13.49^{* *}\end{array}$ & & $-5.07^{* *}$ & $\begin{array}{l}0.70 \\
1385 * *\end{array}$ & & $-4.65^{*}$ & -0.24 & $\begin{array}{l}-3.22 \\
13.51 *\end{array}$ & -0.74 \\
\hline $\begin{array}{l}\text { Polity IV:Autocracy } \\
\text { Assembly-Elected } \\
\text { President }\end{array}$ & $\begin{array}{l}13.49^{\text {** }} \\
1.85\end{array}$ & -3.04 & 9.12 & $\begin{array}{l}13.85^{* *} \\
-7.94^{* *}\end{array}$ & $-13.36+$ & -2.74 & 0.80 & $\begin{array}{l}13.51^{*} \\
-5.25\end{array}$ & 1.65 \\
\hline $\begin{array}{l}\text { Vote Threshold } \\
(\log +1)\end{array}$ & 0.01 & $-7.62^{*}$ & $-17.37+$ & 3.07 & $-7.78^{*}$ & $-5.45^{*}$ & -0.51 & 5.41 & -0.66 \\
\hline $\begin{array}{l}\text { Sim. Parl. \& Pres. } \\
\text { Elections }\end{array}$ & $6.59^{*}$ & 5.74 & 3.27 & -1.48 & & $11.16+$ & $6.72^{*}$ & -3.88 & $6.03^{*}$ \\
\hline residential Election & 1.27 & 2.57 & $-10.58^{* *}$ & $7.54^{* *}$ & 2.19 & 2.17 & -0.94 & 9.90 & 0.65 \\
\hline Margin of Majority & 4.81 & -2.51 & 0.02 & 0.50 & 35.95 & $15.80+$ & 2.32 & -8.69 & 5.63 \\
\hline $\begin{array}{l}\text { External Vote } \\
\text { Possible }\end{array}$ & -3.00 & -2.13 & 2.49 & -2.37 & -15.07 & 5.74 & -2.77 & 3.34 & $-3.31+$ \\
\hline $\begin{array}{l}\text { Postal or E-Voting } \\
\text { Possible }\end{array}$ & -1.60 & -1.78 & 2.56 & & $6.74+$ & 1.78 & -1.32 & & -1.19 \\
\hline Vote Fraud & 0.77 & 5.59 & -1.71 & 0.30 & & & 3.32 & & 0.83 \\
\hline density & $-0.09^{* *}$ & -0.02 & $-0.22 *$ & $-0.20^{* *}$ & -0.04 & -0.04 & $9 * *$ & 0.02 & $-0.08^{* *}$ \\
\hline 34) Pop. & 0.18 & -0.33 & -0.01 & 0.89 & $-1.47^{*}$ & -0.02 & 0.3 & $3.92^{* *}$ & 0.26 \\
\hline$\%$ Rur & $0.29^{*}$ & 0.11 & 0.36 & 0.29 & -0.14 & -0.11 & 0.11 & -0.06 & $0.23+$ \\
\hline Islam Country & $-7.67^{*}$ & & 15.66 & $-10.98^{*}$ & & 12.10 & -2.00 & -10.06 & -5.47 \\
\hline $\begin{array}{l}\text { Non-European } \\
\text { Country }\end{array}$ & $-4.02+$ & & & $-16.98^{* *}$ & & & & $-16.93^{*}$ & -3.85 \\
\hline GDPGrowth (t-1) & $-0.11^{*}$ & $-0.17+$ & -0.02 & $-0.16^{* *}$ & -0.01 & -0.12 & $-0.10^{*}$ & -0.03 & $-0.09 *$ \\
\hline $\begin{array}{l}\text { Fractionalization } \\
\text { Index }\end{array}$ & 3.67 & 7.20 & 10.66 & 3.93 & $47.91^{*}$ & 23.74 & 5.92 & 3.80 & 5.14 \\
\hline $\begin{array}{l}\text { Opposition Fract. } \\
\text { Index }\end{array}$ & $-6.63^{*}$ & $-13.26^{* *}$ & -4.80 & -2.84 & $-22.75^{*}$ & -7.22 & $-8.36^{* *}$ & -3.96 & $-8.02^{* *}$ \\
\hline $\begin{array}{l}\text { Election Importance } \\
\text { Hight+ }\end{array}$ & $6.90^{* *}$ & $9.88^{* *}$ & $-4.20^{* *}$ & 0.13 & $10.12^{* *}$ & $9.26^{* *}$ & $5.28^{* *}$ & -1.87 & $6.45^{* *}$ \\
\hline $\begin{array}{l}\text { EU Status- } \\
\text { Member } † \dagger \dagger\end{array}$ & $-7.29^{* *}$ & 0.30 & & & & $-8.33^{* *}$ & $-7.85^{* *}$ & & $-6.73^{*}$ \\
\hline $\begin{array}{l}\text { EU Status - } \\
\text { Candidate } † \dagger \dagger\end{array}$ & $-5.14^{* *}$ & 1.07 & $-5.74^{*}$ & & & & $-3.99 *$ & & $-4.48^{*}$ \\
\hline $\begin{array}{l}\text { Overall Globali- } \\
\text { zation Index }\end{array}$ & $-0.24^{* *}$ & $-0.33^{* *}$ & 0.13 & $-0.81^{* *}$ & $1.01+$ & 0.22 & $-0.25^{*}$ & -0.45 & $-0.28^{* *}$ \\
\hline Migration rate & $-0.38^{* *}$ & -0.34 & $-1.23^{* *}$ & 0.15 & 0.31 & $-0.60^{*}$ & $-0.83^{* *}$ & $-0.87^{*}$ & $-0.52^{* *}$ \\
\hline Constant & $78.96^{* *}$ & $110.00^{* *}$ & $87.86^{*}$ & $82.24^{* *}$ & & 35.63 & $88.20^{* *}$ & -3.81 & $81.44^{* *}$ \\
\hline$R^{2}$ & 0.74 & 0.79 & 0.88 & 0.73 & 0.95 & 0.54 & 0.75 & 0.74 & 0.73 \\
\hline$N$ & 272 & 95 & 59 & 118 & 31 & 85 & 183 & 57 & 238 \\
\hline
\end{tabular}

Regression coefficients (xtpcse); 30 countries; 272 cases (elections); $+p<0.1{ }^{*} p<0.05$; ${ }^{*} p<0.01$

$\dagger$ The initial model included some other independent variables which were excluded from the final model for reasons related to low sample size, too many predictors and non-significance (Freedom House Index, Political System Presidential, Proportional Representation, Unicameralism, District Magnitude Candidates (log), Human Development Index, Gini Index, GDP Per Capita, PPP (constant 2005 int. \$), GDP Growth (annual \%) related to the first year in the dataset (sqrt*10), Unemployment (\% of total labor force), Inflation, consumer prices (log+10)).

†† Parliamentary Elections in Parliamentary System or Presidential Elections in Presidential System.

$\dagger+\dagger$ at the time of elections. 


\section{Table 2b. Robustness checks: Explaining turnout decline in post-communist countries (VAP turnout) $\dagger$}

\begin{tabular}{|c|c|c|c|c|c|c|c|c|c|}
\hline $\begin{array}{l}\text { Independent } \\
\text { variables }\end{array}$ & $\begin{array}{l}\text { All } \\
\text { cases }\end{array}$ & $\begin{array}{c}\text { EU } \\
\text { member } \\
\text { (present) }\end{array}$ & $\begin{array}{c}\text { EU } \\
\text { candidate } \\
\text { (present) }\end{array}$ & $\begin{array}{c}\text { Non EU } \\
\text { (present) }\end{array}$ & $\begin{array}{c}\text { EU } \\
\text { member } \\
+\dagger \dagger\end{array}$ & $\begin{array}{c}\text { EU } \\
\text { member / } \\
\text { candidate } \\
+\dagger \dagger\end{array}$ & $\begin{array}{c}\text { European } \\
\text { country }\end{array}$ & $\begin{array}{c}\text { Electoral } \\
\text { fraud }\end{array}$ & $\begin{array}{l}\text { Non- } \\
\text { Autoc- } \\
\text { racy }\end{array}$ \\
\hline Election Sequence & -0.07 & -0.26 & -0.64 & 0.75 & $-0.96^{*}$ & -0.01 & -0.24 & -1.92 & -0.03 \\
\hline Polity Fragmentation & $-4.43^{* *}$ & & $-6.48^{* *}$ & 0.19 & & $-6.35^{* *}$ & $-4.73^{* *}$ & $-6.57^{* *}$ & $-4.49^{* *}$ \\
\hline Polity IV: Autocracy & $10.57^{* *}$ & & & $12.31^{* *}$ & & & & $9.48+$ & \\
\hline $\begin{array}{l}\text { Assembly-Elected } \\
\text { President }\end{array}$ & -0.40 & -2.53 & $12.65+$ & $-8.94^{* *}$ & $-19.57^{* *}$ & 1.46 & 0.15 & -4.42 & -0.05 \\
\hline Vote Threshold $(\log +1)$ & -3.10 & $-10.66^{* *}$ & -18.45 & 5.25 & $-10.77^{* *}$ & $-4.88^{*}$ & $-5.74^{*}$ & 5.50 & $-4.19+$ \\
\hline Sim. Parl. \& Pres. Elections & $9.82^{* *}$ & 7.86 & 3.52 & $12.83^{* *}$ & & $11.97^{*}$ & $7.05^{*}$ & 3.70 & $9.35^{* *}$ \\
\hline Presidential Election & $1.96^{*}$ & $3.90 *$ & $-6.41^{* *}$ & $8.00^{* *}$ & 3.65 & $3.48+$ & 0.23 & 8.53 & 1.01 \\
\hline Margin of Majority & $7.75^{*}$ & 2.87 & -12.76 & 1.13 & $38.37^{*}$ & $22.53^{*}$ & 5.65 & -4.94 & $7.96+$ \\
\hline External Vote Possible & $-4.56^{*}$ & -3.50 & 6.47 & -3.47 & 3.58 & 2.92 & -2.03 & 4.35 & $-4.10^{*}$ \\
\hline Postal orE-Voting Possible & $-7.45^{* *}$ & $-7.37^{* *}$ & $-16.00+$ & & $5.32^{*}$ & $-4.23^{*}$ & $-8.53^{* *}$ & & $-7.35^{* *}$ \\
\hline Vote Fraud & 1.69 & 5.73 & 4.44 & 2.61 & & & 2.84 & & 1.10 \\
\hline Population density & 0.03 & $0.11^{*}$ & 0.07 & $-0.09+$ & $0.11+$ & $0.10^{*}$ & 0.02 & $0.36^{* *}$ & 0.04 \\
\hline \% Youth (15-34) Pop. & $-0.66+$ & -1.11 & -1.42 & $1.51^{*}$ & $-3.63^{* *}$ & $-1.62^{* *}$ & $-1.27^{* *}$ & 1.75 & $-0.80^{*}$ \\
\hline \% Rural Pop. & 0.13 & 0.13 & -0.01 & -0.20 & -0.05 & 0.15 & 0.17 & $-0.55+$ & 0.13 \\
\hline Islam Country & -1.24 & & 21.17 & -6.60 & & 4.75 & 5.09 & 11.37 & -0.23 \\
\hline Non-European Country & $-4.45^{*}$ & & & $-13.89 * *$ & & & & 2.63 & -3.49 \\
\hline GDP Growth (t-1) & -0.03 & 0.16 & -0.01 & -0.06 & $0.26+$ & -0.03 & -0.01 & $0.13+$ & -0.00 \\
\hline Fractionalization Index & $9.83^{* *}$ & $12.21+$ & $18.89^{*}$ & $9.60^{*}$ & $52.18^{* *}$ & 18.53 & $12.93^{* *}$ & 3.47 & $11.70^{* *}$ \\
\hline Opposition Fract. Index & $-8.42^{* *}$ & $-16.55^{* *}$ & -5.19 & $-8.43^{*}$ & $-27.23^{* *}$ & $-10.75+$ & $-8.99^{* *}$ & -3.43 & $-10.13^{* *}$ \\
\hline $\begin{array}{l}\text { Election Importance } \\
\text { High } \dagger \dagger\end{array}$ & $6.55^{* *}$ & $9.81^{* *}$ & -1.12 & 0.18 & $10.23^{* *}$ & $9.68^{* *}$ & $5.15^{* *}$ & -0.74 & $5.74^{* *}$ \\
\hline EU Status-Member †† & $-7.21^{* *}$ & 0.87 & & & & $-9.36^{* *}$ & $-6.07^{*}$ & & $-7.71^{* *}$ \\
\hline $\begin{array}{l}\text { EU Status - Candidate } \\
\dagger+\dagger\end{array}$ & -2.57 & 2.64 & $-5.15+$ & & & & -1.13 & & -2.57 \\
\hline $\begin{array}{l}\text { Overall Globalization } \\
\text { Index }\end{array}$ & $-0.23^{* *}$ & $-0.60^{* *}$ & 0.33 & $-0.73^{* *}$ & $1.19^{* *}$ & -0.01 & $-0.23^{*}$ & -0.20 & $-0.23^{*}$ \\
\hline Migration rate & $-0.41^{* *}$ & -0.35 & $-0.78+$ & $-0.29+$ & $1.75^{* *}$ & -0.21 & $-0.63^{* *}$ & $-1.08^{* *}$ & $-0.47^{* *}$ \\
\hline Constant & $95.14^{* *}$ & $129.90^{* *}$ & $107.71^{*}$ & $70.58^{* *}$ & & $74.47^{* *}$ & $116.01^{* *}$ & 34.49 & $99.86^{* *}$ \\
\hline$R^{2}$ & 0.67 & 0.80 & 0.76 & 0.67 & 0.99 & 0.65 & 0.69 & 0.72 & 0.65 \\
\hline$N$ & 272 & 95 & 59 & 118 & 31 & 85 & 183 & 57 & 238 \\
\hline
\end{tabular}

Regression coefficients (xtpcse); 30 countries; 272 cases (elections); $+p<0.1$; ${ }^{*} p<0.05$; ** $p<0.01$

$\dagger$ The initial model included some other independent variables which were excluded from the final model for reasons related to low sample size, too many predictors and non-significance (Freedom House Index, Political System Presidential, Proportional Representation, Unicameralism, District Magnitude Candidates (log), Human Development Index, Gini Index, GDP Per Capita, PPP (constant 2005 int. \$), GDP Growth (annual \%) related to the first year in the dataset (sqrt*10), Unemployment (\% of total labor force), Inflation, consumer prices (log+10)).

†† Parliamentary Elections in Parliamentary System or Presidential Elections in Presidential System.

†† $†$ at the time of elections. 
Table 3a. Model robustness of the migration effect on turnout

\begin{tabular}{|l|l|l|}
\hline Model Robustness Statistics & REG & VAP \\
\hline Mean(b) & -0.655 & -0.513 \\
\hline Sampling SE & 0.221 & 0.191 \\
\hline Modelling SE & 0.193 & 0.158 \\
\hline Total SE & 0.293 & 0.248 \\
\hline Robustness Ratio & -2.233 & -2.072 \\
\hline
\end{tabular}

Number of models 1,310,720

\begin{tabular}{|l|l|l|}
\hline Significance Testing & REG & VAP \\
\hline Sign Stability & $100 \%$ & $100 \%$ \\
\hline Significance rate & $97 \%$ & $97 \%$ \\
\hline Positive & $0 \%$ & $0 \%$ \\
\hline Positive and Sig & $0 \%$ & $0 \%$ \\
\hline Negative & $100 \%$ & $100 \%$ \\
\hline Negative and Sig & $97 \%$ & $97 \%$ \\
\hline
\end{tabular}

Table 3b. Model robustness of the migration effect on turnout*

\begin{tabular}{|l|l|l|l|l|}
\hline Independent variable* & \multicolumn{2}{|l|}{ Marginal effect of variable inclusion } & \multicolumn{2}{l|}{ Percent change from mean(b) } \\
\hline Turnout & REG & VAP & REG & VAP \\
\hline Polity fragmentation & - & 0.112 & - & $-21.8 \%$ \\
\hline model: xtreg(FE) & -0.280 & 0.098 & $42.8 \%$ & $-19.2 \%$ \\
\hline model: xtreg(RE) & -0.116 & - & $17.6 \%$ & - \\
\hline Election sequence & 0.086 & 0.066 & $-13.1 \%$ & $-12.8 \%$ \\
\hline Population density & 0.071 & - & $-10.8 \%$ & - \\
\hline Overall globalization & - & -0.055 & - & $10.8 \%$ \\
\hline
\end{tabular}

* Only independent variables with percent change from mean greater than $10 \%$ are presented. 


\section{Table 4a. Interactions effects: Explaining turnout decline in post-communist countries (registered turnout) $\dagger$}

\begin{tabular}{|c|c|c|c|c|c|c|}
\hline Independent variables & $\begin{array}{c}\text { No } \\
\text { interactions }\end{array}$ & $\begin{array}{l}\text { External } \\
\text { vote }\end{array}$ & $\begin{array}{l}\text { Mail / } \\
\text { E-vote }\end{array}$ & $\begin{array}{l}\text { Electoral } \\
\text { fraud }\end{array}$ & $\begin{array}{c}\text { Non- } \\
\text { European }\end{array}$ & Autocracy \\
\hline Election Sequence & -0.50 & -0.41 & -0.47 & -0.54 & -0.34 & -0.46 \\
\hline Polity Fragmentation & -1.66 & $-1.95+$ & -1.85 & -1.74 & -1.31 & -1.67 \\
\hline Polity IV: Autocracy & $13.49^{* *}$ & $12.03^{* *}$ & $13.50 * *$ & $13.92^{* *}$ & $13.00^{* *}$ & 10.56 \\
\hline Assembly-Elected President & 1.85 & 1.54 & 1.90 & 1.96 & 1.04 & 1.75 \\
\hline Vote Threshold $(\log +1)$ & 0.01 & -0.25 & -0.31 & -0.05 & -0.33 & -0.08 \\
\hline Sim. Parl. \& Pres. Elections & $6.59 *$ & $6.01^{*}$ & $6.23^{*}$ & $6.35^{*}$ & $6.94^{*}$ & $6.70^{*}$ \\
\hline Presidential Election & 1.27 & 1.12 & 1.23 & 1.32 & 1.14 & 1.24 \\
\hline Margin of Majority & 4.81 & 4.13 & 4.76 & 4.91 & 4.30 & 5.06 \\
\hline External Vote Possible & -3.00 & $-9.65^{* *}$ & $-3.06+$ & $-3.13+$ & $-3.46+$ & $-3.19+$ \\
\hline Postal or E-Voting Possible & -1.60 & -1.46 & -3.71 & -1.59 & -1.01 & -1.46 \\
\hline Vote Fraud & 0.77 & 1.07 & 0.78 & 5.70 & 0.57 & 0.57 \\
\hline Population density & $-0.09 * *$ & $-0.08^{* *}$ & $-0.09 * *$ & $-0.09^{* *}$ & $-0.11^{* *}$ & $-0.09 * *$ \\
\hline \% Youth (15-34) Pop. & 0.18 & 0.19 & 0.18 & 0.23 & 0.23 & 0.19 \\
\hline \% Rural Pop. & $0.29 *$ & $0.27^{*}$ & $0.30^{*}$ & $0.28^{*}$ & $0.26^{*}$ & $0.29 *$ \\
\hline Islam Country & $-7.67^{*}$ & $-6.30+$ & $-8.34 *$ & $-8.41^{*}$ & -5.28 & $-7.72^{*}$ \\
\hline Non-European Country & $-4.02+$ & $-4.04+$ & -3.72 & -3.90 & $-15.16^{* *}$ & -3.96 \\
\hline GDP Growth (t-1) & $-0.11^{*}$ & $-0.11^{*}$ & $-0.11^{*}$ & $-0.10^{*}$ & $-0.10^{*}$ & $-0.11^{*}$ \\
\hline Fractionalization Index & 3.67 & 3.83 & 3.63 & 4.00 & 3.98 & 3.93 \\
\hline Opposition Fract. Index & $-6.63^{*}$ & $-6.71^{*}$ & $-6.42 *$ & $-6.71^{*}$ & $-8.30 * *$ & $-7.02 *$ \\
\hline Election Importance High †† & $6.90^{* *}$ & $6.95^{* *}$ & $6.91^{* *}$ & $6.87^{* *}$ & $7.08^{* *}$ & $6.90^{* *}$ \\
\hline EU Status - Member $+\dagger \dagger$ & $-7.29^{* *}$ & $-6.63^{*}$ & $-7.19^{* *}$ & $-7.49^{* *}$ & $-7.09^{* *}$ & $-7.17^{* *}$ \\
\hline EU Status - Candidate ††† & $-5.14^{* *}$ & $-4.77^{* *}$ & $-5.21^{* *}$ & $-5.30 * *$ & $-4.80 * *$ & $-5.03^{* *}$ \\
\hline Overall Globalization Index & $-0.24^{* *}$ & $-0.26^{* *}$ & $-0.24^{* *}$ & $-0.22^{*}$ & $-0.30 * *$ & $-0.26^{* *}$ \\
\hline Migration rate & $-0.38^{* *}$ & $-0.77^{* *}$ & $-0.40^{* *}$ & $-0.32^{*}$ & $-0.63^{* *}$ & $-0.40^{* *}$ \\
\hline $\begin{array}{l}\text { Migration rate \# External } \\
\text { Vote }\end{array}$ & & $0.52^{* *}$ & & & & \\
\hline $\begin{array}{l}\text { Migration rate \# Mail / } \\
\text { E-Vote }\end{array}$ & & & 0.16 & & & \\
\hline Migration rate \# Vote Fraud & & & & -0.33 & & \\
\hline $\begin{array}{l}\text { Migration rate \# Non- } \\
\text { European }\end{array}$ & & & & & $0.65^{* *}$ & \\
\hline Migration rate \# Autocracy & & & & & & 0.20 \\
\hline Constant & $78.96^{* *}$ & $84.30 * *$ & $78.86^{* *}$ & $76.26^{* *}$ & $86.99^{* *}$ & $79.69 * *$ \\
\hline$R^{2}$ & 0.74 & 0.75 & 0.74 & 0.74 & 0.74 & 0.74 \\
\hline$N$ & 272 & 272 & 272 & 272 & 272 & 272 \\
\hline
\end{tabular}

Regression coefficients (xtpcse); 30 countries; 272 cases (elections); $+p<0.1{ }^{*} p<0.05$; $^{* *} p<0.01$

$\dagger$ The initial model included some other independent variables which were excluded from the final model for reasons related to low sample size, too many predictors and non-significance (Freedom House Index, Political System - Presidential, Proportional Representation, Unicameralism, District Magnitude Candidates (log), Human Development Index, Gini Index, GDP Per Capita, PPP (constant 2005 int. \$), GDP Growth (annual \%) related to the first year in the dataset (sqrt* 10), Unemployment (\% of total labour force), Inflation, consumer prices (log+10)). †† Parliamentary Elections in Parliamentary System or Presidential Elections in Presidential System. $\dagger+\dagger$ at the time of elections. 


\section{Table 4b. Interactions effects: Explaining turnout decline in post-communist countries (VAP turnout) $\dagger$}

\begin{tabular}{|c|c|c|c|c|c|c|}
\hline Independent variables & $\begin{array}{c}\text { No } \\
\text { interactions }\end{array}$ & $\begin{array}{l}\text { External } \\
\text { vote }\end{array}$ & $\begin{array}{l}\text { Mail / } \\
\text { E-vote }\end{array}$ & $\begin{array}{l}\text { Electoral } \\
\text { fraud }\end{array}$ & $\begin{array}{c}\text { Non- } \\
\text { European }\end{array}$ & Autocracy \\
\hline Election Sequence & -0.07 & -0.01 & -0.09 & -0.07 & -0.04 & -0.10 \\
\hline Polity Fragmentation & $-4.43^{* *}$ & $-4.57^{* *}$ & $-4.33^{* *}$ & $-4.43^{* *}$ & $-4.37^{* *}$ & $-4.41 * *$ \\
\hline Polity IV: Autocracy & $10.57^{* *}$ & $9.88^{* *}$ & $10.56^{* *}$ & $10.59 * *$ & $10.48^{* *}$ & $13.16^{*}$ \\
\hline Assembly-Elected President & -0.40 & -0.56 & -0.42 & -0.40 & -0.56 & -0.32 \\
\hline Vote Threshold $(\log +1)$ & -3.10 & -3.23 & -2.92 & -3.11 & -3.11 & -3.07 \\
\hline Sim. Parl. \& Pres. Elections & $9.82^{* *}$ & $9.53^{* *}$ & $10.03^{* *}$ & $9.81^{* *}$ & $9.87^{* *}$ & $9.71^{* *}$ \\
\hline Presidential Election & $1.96^{*}$ & $1.88+$ & $1.97^{*}$ & $1.96^{*}$ & $1.94^{*}$ & $1.97^{*}$ \\
\hline Margin of Majority & $7.75^{*}$ & $7.39+$ & $7.78^{*}$ & $7.76^{*}$ & $7.57+$ & $7.53+$ \\
\hline External Vote Possible & $-4.56^{*}$ & $-7.72 *$ & $-4.50 *$ & $-4.57^{*}$ & $-4.62 *$ & $-4.40^{*}$ \\
\hline Postal or E-Voting Possible & $-7.45^{* *}$ & $-7.40 * *$ & $-6.48+$ & $-7.44^{* *}$ & $-7.33^{* *}$ & $-7.57 * *$ \\
\hline Vote Fraud & 1.69 & 1.84 & 1.68 & 1.91 & 1.57 & 1.91 \\
\hline Population density & 0.03 & 0.03 & 0.02 & 0.03 & 0.02 & 0.03 \\
\hline \% Youth (15-34) Pop. & $-0.66+$ & $-0.66^{*}$ & $-0.66+$ & $-0.66+$ & $-0.65+$ & $-0.66+$ \\
\hline \% Rural Pop. & 0.13 & 0.13 & 0.13 & 0.13 & 0.13 & 0.13 \\
\hline Islam Country & -1.24 & -0.59 & -0.91 & -1.27 & -0.67 & -1.21 \\
\hline Non-European Country & $-4.45^{*}$ & $-4.45^{*}$ & $-4.60^{*}$ & $-4.44^{*}$ & -6.93 & $-4.51 *$ \\
\hline GDP Growth (t-1) & -0.03 & -0.03 & -0.03 & -0.03 & -0.03 & -0.03 \\
\hline Fractionalization Index & $9.83^{* *}$ & $9.94^{* *}$ & $9.86^{* *}$ & $9.84^{* *}$ & $9.88^{* *}$ & $9.57^{* *}$ \\
\hline Opposition Fract. Index & $-8.42^{* *}$ & $-8.38^{* *}$ & $-8.55^{* *}$ & $-8.42^{* *}$ & $-8.84^{* *}$ & $-8.00 * *$ \\
\hline Election Importance High $\dagger \dagger$ & $6.55^{* *}$ & $6.58^{* *}$ & $6.54^{* *}$ & $6.55^{* *}$ & $6.58^{* *}$ & $6.54^{* *}$ \\
\hline EU Status - Member $\dagger \dagger \dagger$ & $-7.21^{* *}$ & $-6.89^{* *}$ & $-7.25^{* *}$ & $-7.23^{* *}$ & $-7.16^{* *}$ & $-7.34^{* *}$ \\
\hline EU Status - Candidate $\uparrow+\uparrow$ & -2.57 & -2.36 & -2.53 & -2.57 & -2.47 & -2.70 \\
\hline Overall Globalization Index & $-0.23^{* *}$ & $-0.24^{* *}$ & $-0.22^{* *}$ & $-0.22^{* *}$ & $-0.24^{* *}$ & $-0.21 *$ \\
\hline Migration rate & $-0.41^{* *}$ & $-0.60 * *$ & $-0.40^{* *}$ & $-0.41^{* *}$ & $-0.46^{* *}$ & $-0.38^{* *}$ \\
\hline $\begin{array}{l}\text { Migration rate \# External } \\
\text { Vote }\end{array}$ & & 0.25 & & & & \\
\hline $\begin{array}{l}\text { Migration rate \# Mail / } \\
\text { E-Vote }\end{array}$ & & & -0.07 & & & \\
\hline Migration rate \# Vote Fraud & & & & -0.01 & & \\
\hline $\begin{array}{l}\text { Migration rate \# Non- } \\
\text { European }\end{array}$ & & & & & 0.14 & \\
\hline Migration rate \# Autocracy & & & & & & -0.18 \\
\hline Constant & $95.14^{* *}$ & $98.03^{* *}$ & $95.07 * *$ & $95.02 * *$ & $97.07 * *$ & $94.42^{* *}$ \\
\hline$R^{2}$ & 0.67 & 0.67 & 0.67 & 0.67 & 0.67 & 0.67 \\
\hline$N$ & 272 & 272 & 272 & 272 & 272 & 272 \\
\hline
\end{tabular}

Regression coefficients (xtpcse); 30 countries; 272 cases (elections); $+p<0.1{ }^{*} p<0.05 ;{ }^{* *} p<0.01$

$\dagger$ The initial model included some other independent variables which were excluded from the final model for reasons related to low sample size, too many predictors and non-significance (Freedom House Index, Political System - Presidential, Proportional Representation, Unicameralism, District Magnitude Candidates (log), Human Development Index, Gini Index, GDP Per Capita, PPP (constant 2005 int. \$), GDP Growth (annual \%) related to the first year in the dataset (sqrt * 10 ), Unemployment (\% of total labor force), Inflation, consumer prices (log+10)).

†† Parliamentary Elections in Parliamentary System or Presidential Elections in Presidential System.

$\dagger \dagger \dagger$ at the time of elections. 
Figure A6. Interactions effects: Explaining turnout decline in post-communist countries (predictive margins with 95\% Cis; models with control variables included)
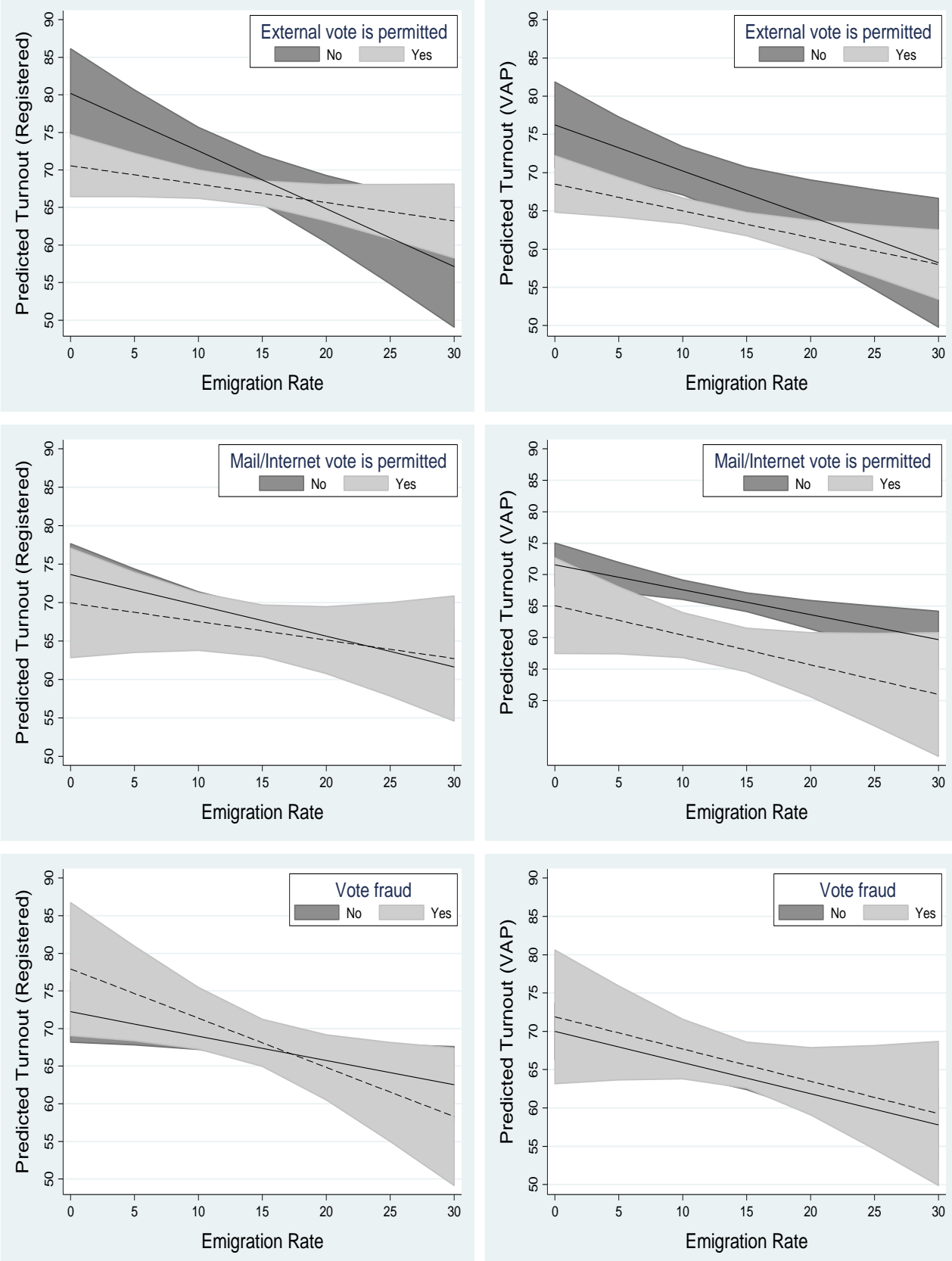

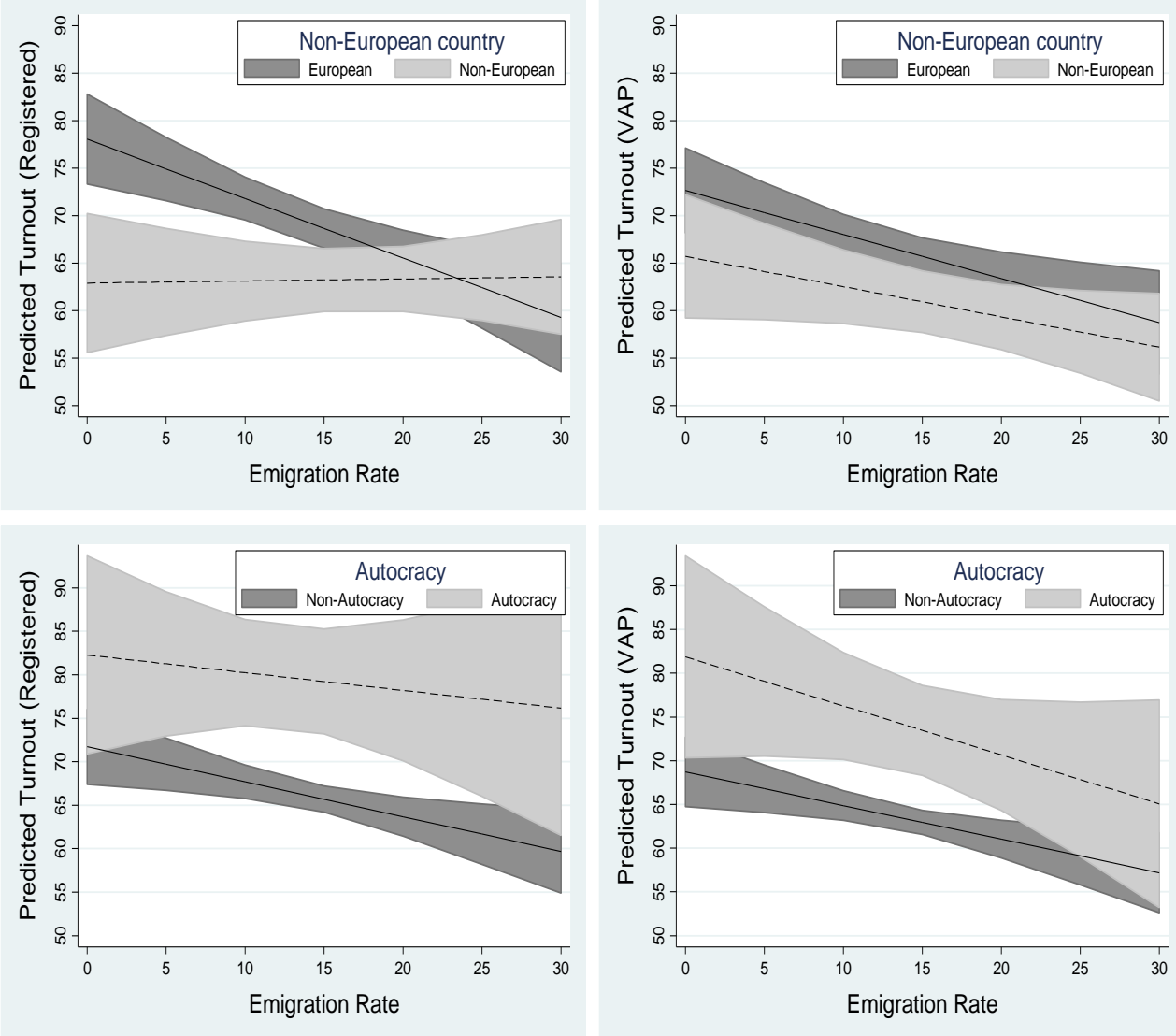